\title{
STRUCTURE AND MECHANICAL PROPERTIES OF 21HMF STEEL STEAM TURBINE ROTOR MATERIALS AFTER LONG-TERM OPERATION FOR A TIME SIGNIFICANTLY EXCEEDING THE DESIGN TIME
}

\author{
STRUKTURA I WŁAŚCIWOŚCI MECHANICZNE MATERIAŁÓW WIRNIKÓW \\ TURBIN PAROWYCH ZE STALI 21HMF PO DEUGOTRWAEEJ PRACY W CZASIE \\ ZNACZNIE PRZEKRACZAJĄCYM OBLICZENIOWY
}

The article presents the results of tests of materials for steam turbine rotors with various degrees of depletion in order to determine the suitability of these components for further operation after significantly exceeding the design working time on the basis of the assessment of the microstructure condition and a set of functional properties.

Keywords: rotor, turbine, microstructure, mechanical properties
W pracy przedstawiono wyniki badań materiałów wirników turbin parowych o różnym stopniu wyeksploatowania $w$ celu określenia przydatności tych elementów do dalszej eksploatacji po znacznym przekroczeniu obliczeniowego czasu pracy na podstawie oceny stanu mikrostruktury i zespotu właściwości użytkowych.

Stowa kluczowe: wirnik, turbina, mikrostruktura, wtaściwości mechaniczne

\section{INTRODUCTION}

The operating time of most of the operated pressure components of power units significantly exceeded the design time, often more than twice. These units are often subject to a modernisation process aimed at increasing their efficiency and effectiveness, taking into account the growing requirements in the field of environmental protection, and extending the safe operation time well beyond the design time. This requires making decisions based on objective information about a specified material state. Such an approach is conditioned by the application of appropriate diagnostic principles and methods of assessing the condition of the components. These methods, however, require knowledge of the changes taking place in the microstructure of the material as a result of long-term operation in creep conditions, resulting in a decrease in their functional properties, leading in the final stage to the loss of the ability to transfer real loads. For these purposes, it is necessary to build material characteristics for long-operated materials with varying degrees of wear.

The components that require an assessment of the condition and suitability for further operation as well as determining the time of further safe operation are the "critical components", which are defined as operating under the most severe temperature and stress conditions. They include components of the boiler pressure part, main steam pipelines and components of steam turbines [1-7]. Rotor shafts, in addition to turbine bodies and blades, are critical components of steam turbines. Based on the obtained results of destructive material tests of turbine rotor components, an assessment was made of the condition and suitability for further operation of long-term operated air and water parts of steam turbine rotors after operation in a time significantly exceeding the design time.

\section{MATERIAL AND SCOPE}

The testing material consisted of:

1. sections of the SP medium-pressure part and WP high-pressure part of a turbine rotor of a $18 \mathrm{~K} 360$ power unit with a nominal power of $360 \mathrm{MW}$ after 220,000 hours of operation in creep conditions,

2. sections of the WP high-pressure part of a turbine rotor of a TK200 power unit with a nominal power of $200 \mathrm{MW}$ after 200,000 hours of operation.

All the tested turbine rotor components were made of low-alloy three-component 21HMF grade steel, according to PN-H-84024:1975. 

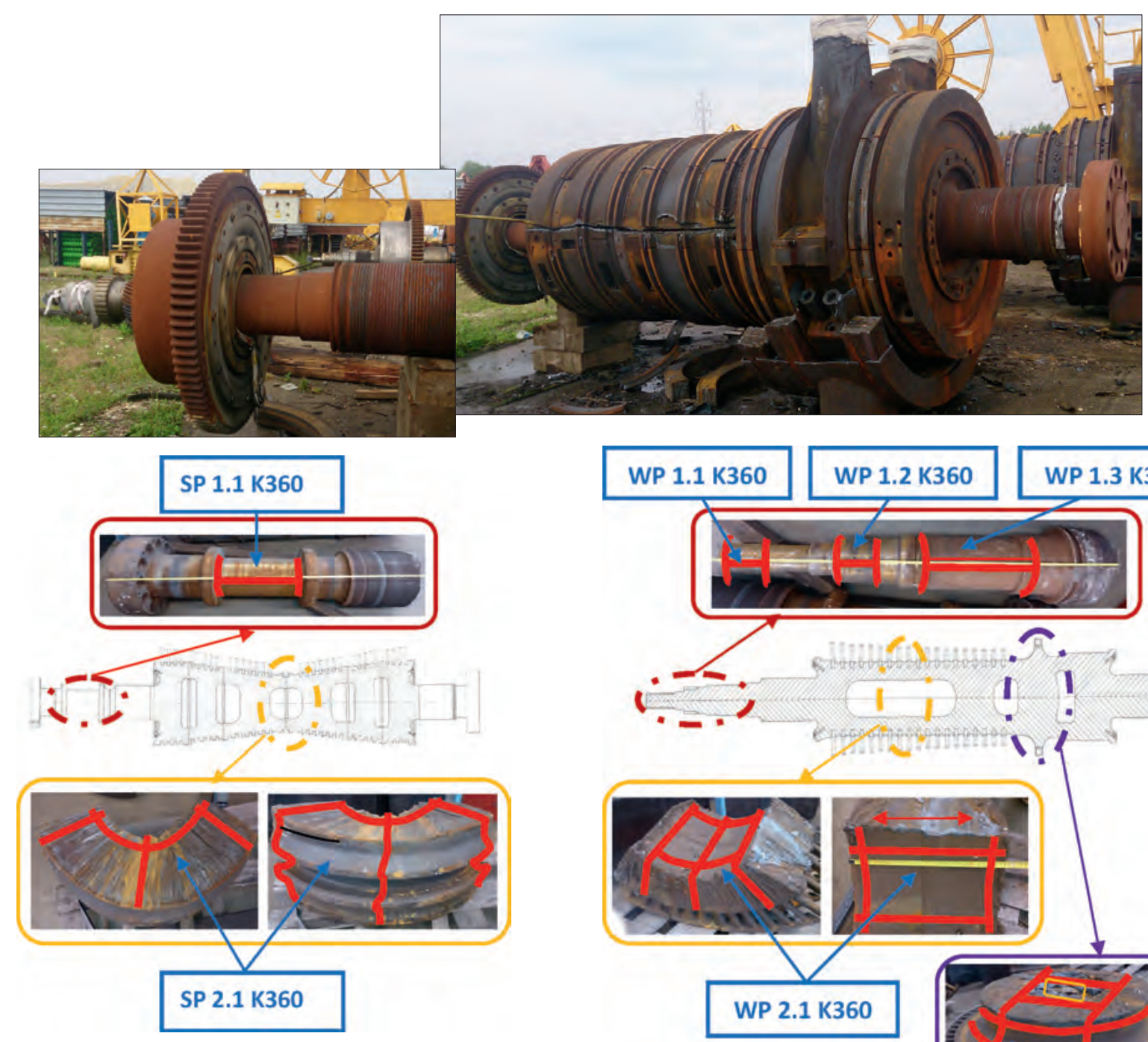

a)

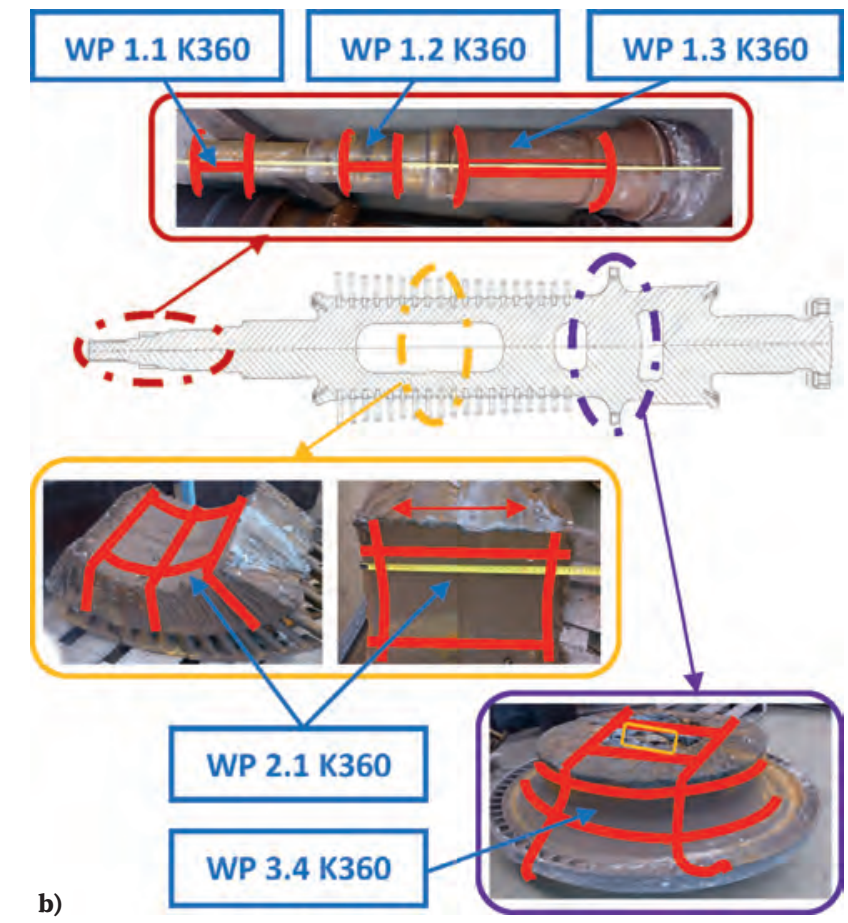

Fig. 1. Method and location of collecting the material for testing on the example of the SP medium-pressure part and WP high-pressure part of a turbine rotor of a $18 \mathrm{~K} 360$ power unit with a nominal power of $360 \mathrm{MW}$ after approx. 220,000 operating hours: a) from SP medium-pressure part, b) from WP high-pressure part

Rys. 1. Sposób i miejsce pobrania materiału do badań na przykładzie części średnioprężnej SP i wysokoprężnej WP wirnika turbiny $18 K 360$ bloku energetycznego o mocy nominalnej 360 MW po ok. 220000 godzin eksploatacji: a) z części średnioprężnej SP, b) z części wysokoprężnej WP

The areas of the rotors from which the material for testing was taken and their operating parameters are summarised in Table 1 and, on the example of a $360 \mathrm{MW}$ unit rotor after 220,000 operating hours, shown in Fig. 1. The test sites were selected in such a way as to obtain the differentiation of the material state from close to the initial state to the state corresponding to operation significantly above the limit temperature, for which creep is the dominant destruction process.

The aim of the study was to search for a correlation between changes in the structure and the corresponding mechanical properties in relation to the requirements for a typical initial state. The obtained results were also used to select the material states, from close to the initial state to the state with the highest degree of depletion, at which, in the next stage of the research, creep resistance and the determined degree of wear will be determined.

In order to achieve the above-defined goal, it was necessary to define and implement the testing agenda, which included:
- structure examination in a scanning electron microscope,

- X-ray analysis of phase composition of precipitates,

- test on strength properties at room temperature and elevated temperature close to the operating temperature,

- impact strength tests and determination of brittle state transition temperature.

\section{RESULTS OF INVESTIGATION}

\subsection{STRUCTURE EXAMINATION IN SCANNING ELECTRON MICROSCOPE}

The microstructure studies were performed using a scanning electron microscope on etched microsections taken from fragments of material sections of rotors of 200 and $360 \mathrm{MW}$ unit steam turbines. The results of microstructure examination for the TK200 turbine rotor material of 
Table 1. Material for destructive testing of WP parts of the TK200 turbine rotor after approx. 200,000 hours of operation, and SP and WP parts of the 21HMF steel $18 \mathrm{~K} 360$ rotor after approx. 220,000 hours of operation and their operating parameters in individual designated test areas Tabela 1. Materiał do badań niszczących części WP wirnika turbiny TK200 po ok. 200000 godzin eksploatacji oraz części SP i WP wirnika $18 K 360$ po ok. 220000 godzin eksploatacji wykonanych ze stali 21 HMF i ich parametry pracy w poszczególnych wyznaczonych obszarach do badań

\begin{tabular}{|c|c|c|c|c|c|c|}
\hline \multirow[b]{2}{*}{ Steel grade } & \multirow[b]{2}{*}{ Component name } & \multirow[b]{2}{*}{$\begin{array}{l}\text { Identification of } \\
\text { tested rotor section }\end{array}$} & \multirow[b]{2}{*}{ Testing location } & \multicolumn{3}{|c|}{ Previous operating parameters } \\
\hline & & & & $\begin{array}{c}\text { Time } \\
t_{\mathrm{e}},[\text { hours] }\end{array}$ & $\begin{array}{c}\text { Temperature } \\
T_{\mathrm{e}},\left[{ }^{\circ} \mathrm{C}\right] \\
\end{array}$ & $\begin{array}{l}\text { Pressure } \\
p_{\mathrm{e}},[\mathrm{MPa}]\end{array}$ \\
\hline \multirow{10}{*}{$21 \mathrm{HMF}$} & $\begin{array}{l}\text { high-pressure part of } \\
\text { TK200 turbine rotor }\end{array}$ & WP.TK200 & $\begin{array}{l}\text { outer disc periphery of the first } \\
\text { uncontrolled steam inlet stage }\end{array}$ & 200,000 & 500 & 14.80 \\
\hline & \multirow{3}{*}{$\begin{array}{l}\text { SP medium-pressure } \\
\text { part of } 18 \mathrm{~K} 360 \text { turbine } \\
\text { rotor }\end{array}$} & SP $1.1 \mathrm{~K} 360$ & $\begin{array}{l}\text { carrier thrust bearing pin } \\
\text { SP part }\end{array}$ & \multirow{9}{*}{220,000} & 40 & 0 \\
\hline & & SP $1.2 \mathrm{~K} 360$ & gland-front & & 240 & 0 \\
\hline & & SP $2.1 \mathrm{~K} 360$ & $\begin{array}{l}\text { rotor's SP part drum in steam inlet } \\
\text { area }\end{array}$ & & 535 & 3.93 \\
\hline & \multirow{6}{*}{$\begin{array}{l}\text { WP high-pressure part } \\
\text { of } 18 \mathrm{~K} 360 \text { turbine rotor }\end{array}$} & WP $1.1 \mathrm{~K} 360$ & WP rotor tip on safety control side & & 20 & 0 \\
\hline & & WP $1.2 \mathrm{~K} 360$ & $\begin{array}{l}\text { place of embedding of device } \\
\text { components for rotor turning }\end{array}$ & & 286 & 0 \\
\hline & & WP 1.3 K360 & rotor's bearing pin & & 398 & 0 \\
\hline & & WP $2.1 \mathrm{~K} 360$ & rotor drum in stage $12-13$ region & & 510 & 14.2 \\
\hline & & WP $3.1 \mathrm{~K} 360$ & \multirow{2}{*}{ steam inlet in control wheel region } & & \multirow[b]{2}{*}{535} & \multirow[b]{2}{*}{17.1} \\
\hline & & WP 3.4 K360 & & & & \\
\hline
\end{tabular}
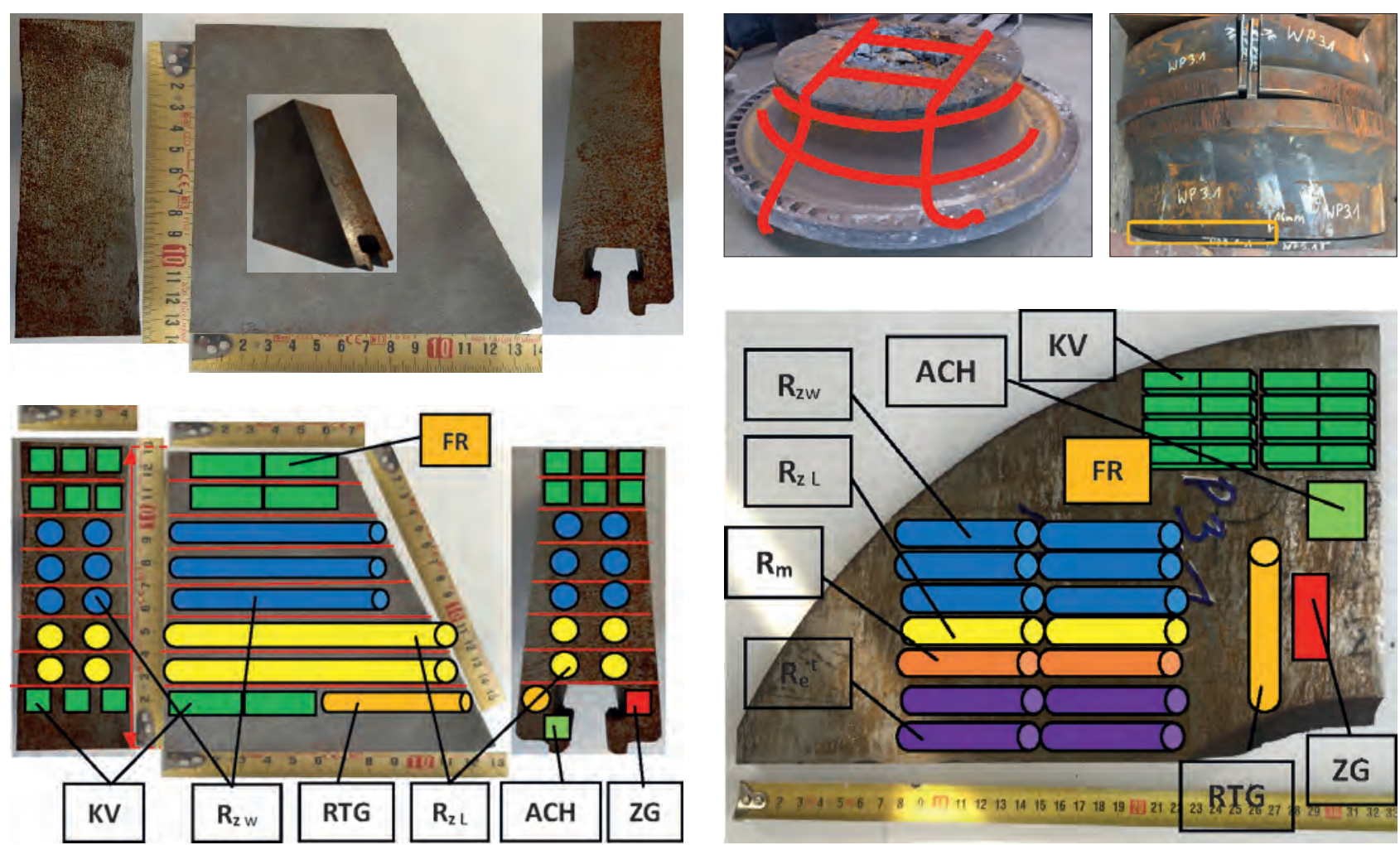

a)

b)

Test samples:

ACH - chemical composition follow-up,

$\mathbf{R}_{\mathbf{e}}{ }^{\mathrm{t}}$ - yield strength at elevated temperature,

ZG - structure on metallographic microsection,

RTG - X-ray analysis of phase composition of precipitates,

$\mathbf{R}_{\mathbf{z} \text { w }}$ - residual creep resistance,

$\mathbf{R}_{\mathrm{m}}$ - tensile strength,

$\mathbf{K V}$ - impact energy,

FR - fractograph of fractures,

$\mathbf{R}_{\mathbf{z}}$ - creep rate in set condition

Fig. 2. Type and location of sampling on the example of: a) TK 200 turbine rotor WP high-pressure part material from the region of outer periphery of first uncontrolled stage after approx. 220,000 operating hours, b) material of the WP high-pressure part of the $18 \mathrm{~K} 360$ turbine rotor in the region of the steam inlet in the region of the regulating wheel after approx. 200,000 operating hours

Rys. 2. Rodzaj i miejsce pobrania próbek do badań na przykładzie: a) materiału części wysokoprężnej WP wirnika turbiny TK $200 \mathrm{z}$ rejonu obrzeża zewnętrznego pierwszego stopnia nieregulowanego po ok. 220000 godzin eksploatacji, b) materiału części wysokoprężnej WP wirnika turbiny $18 \mathrm{~K} 360 \mathrm{w}$ rejonie wlot pary w rejonie koła regulacyjnego po ok. 200000 godzin eksploatacji 
TK 200

ID WP.TK200

steel 21HMF, hardness 195 HV10
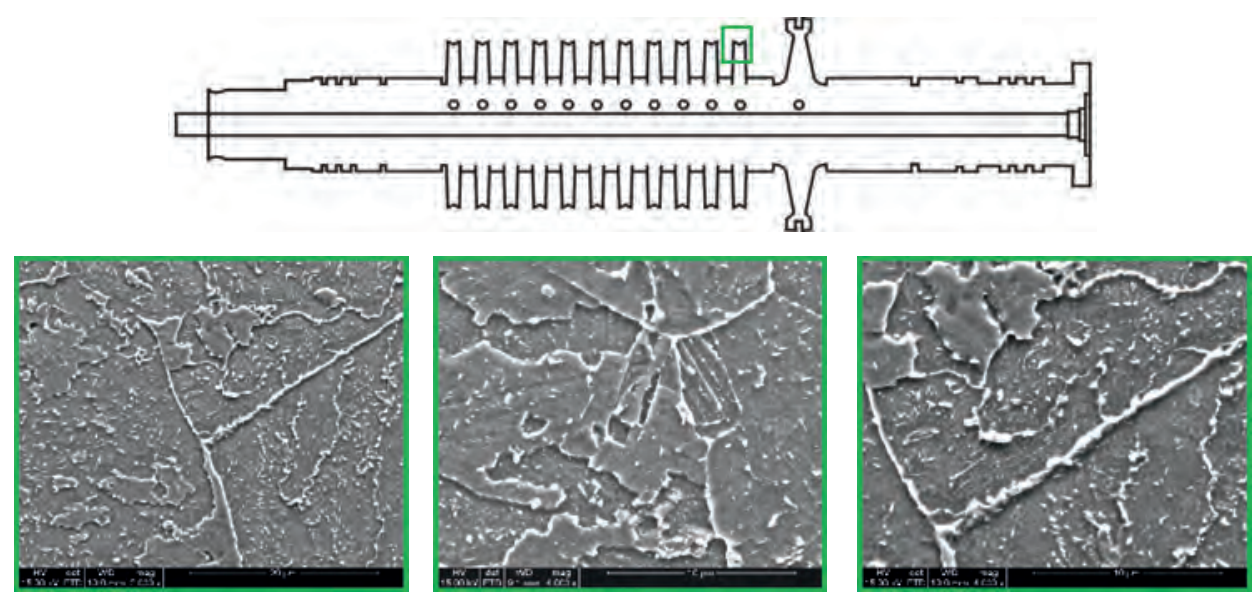

CLASS 2/3 (I, a/b, O); $\mathrm{t}_{\mathrm{e}} / \mathrm{t}_{\mathrm{r}}=$ approx. 0.4

Fig. 3. Microstructure of the material in the area of the outer periphery of the disc of the first unregulated steam inlet stage of the WP high-pressure part of the TK 200 turbine rotor made of 21HMF steel after 200,000 hours of operation, observed on a crosswise microsection using a scanning electron microscope

Rys. 3. Mikrostruktura materiału w obszarze zewnętrznego obrzeża tarczy pierwszego nieregulowanego stopnia wlotu pary części wysokoprężnej WP wirnika turbiny TK 200 wykonanego ze stali 21HMF po 200000 godzin eksploatacji obserwowana na zgładzie poprzecznym w skaningowym mikroskopie elektronowym

ID SP 1.1 K360, steel 21HMF, hardness 240 HV10 steel 21HMF, hardness 242 HV10

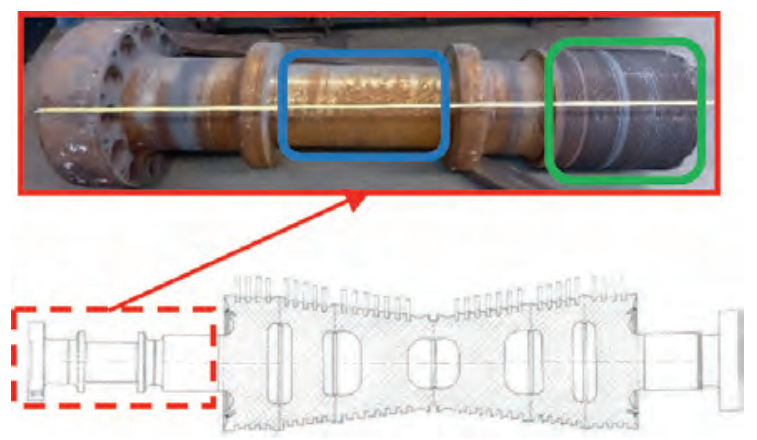

$\operatorname{CLASS} O(0,0,0) ; t_{\mathrm{e}} / \mathrm{t}_{\mathrm{r}}=0$
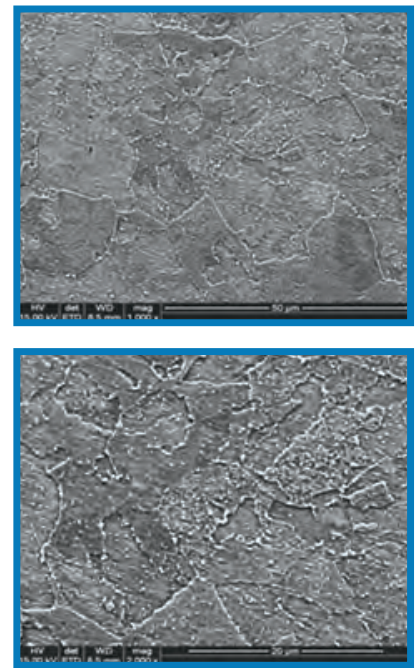

a)
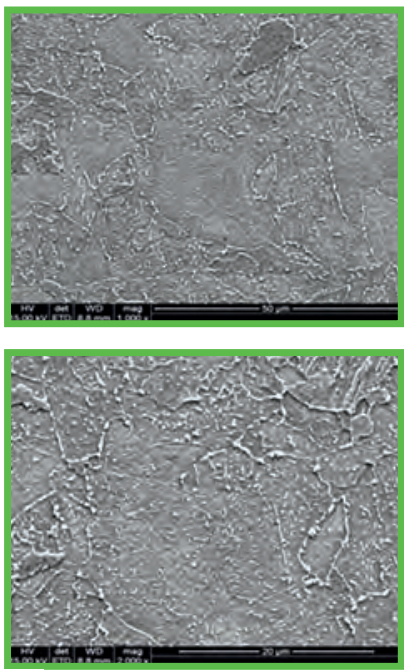

b)
$18 \mathrm{~K} 360$

ID SP 2.1 K360, steel 21HMF, hardness 247 HV10

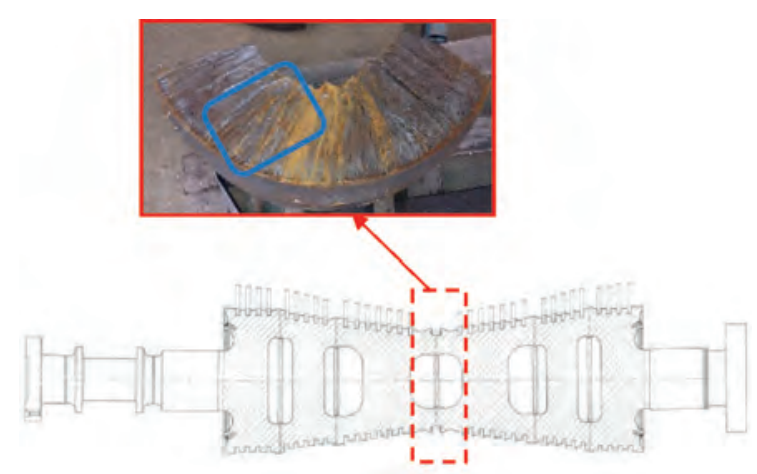

CLASS 1 (0/I, o/a, O); $\mathrm{t}_{\mathrm{e}} / \mathrm{t}_{\mathrm{r}}=$ approx. 0.2
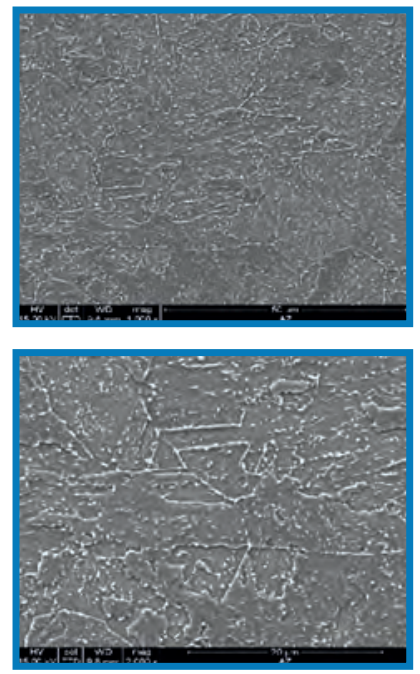

c)

Fig. 4. Microstructure of the material of the SP medium-pressure part of the $18 \mathrm{~K} 360$ turbine rotor after 220,000 hours of operation observed on etched transverse microsections using a scanning electron microscope: a) in carrier thrust bearing pin (ID SP 1.1 K360), b) in the front of the gland (ID SP 1.2 K360), c) in the drum in the steam inlet region (ID SP 2.1 K360)

Rys. 4. Mikrostruktura materiału części średnioprężnej SP wirnika turbiny $18 \mathrm{~K} 360$ po 220 tys. godzin eksploatacji obserwowana na trawionych poprzecznych zgładach metalograficznych w skaningowym mikroskopie elektronowym: a) w czopie łożyska oporowo-nośnego (ozn. SP 1.1 K360), b) w części przedniej dławicy (ozn. SP 1.2 K360), c) w bębnie w rejonie wlotu pary (ozn. SP 2.1 K360) 


\section{$18 \mathrm{~K} 360$}

ID WP $1.1 \mathrm{~K} 360$,

steel 21HMF, hardness $244 \mathrm{HV} 10$

ID WP 1.2 K360,

steel 21HMF, hardness 238 HV10

ID WP $1.3 \mathrm{~K} 360$;

steel 21HMF, hardness $235 \mathrm{HV}$

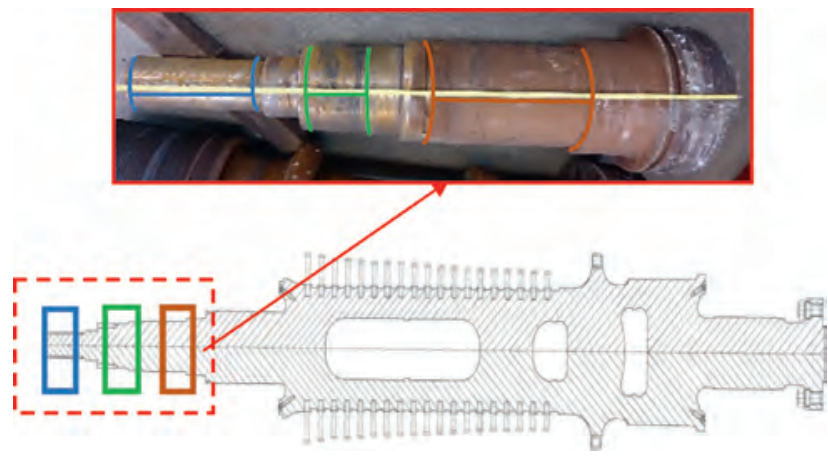

$\operatorname{CLASS~O}(0,0,0) ; t_{\mathrm{e}} / \mathrm{t}_{\mathrm{r}}=0$

a)

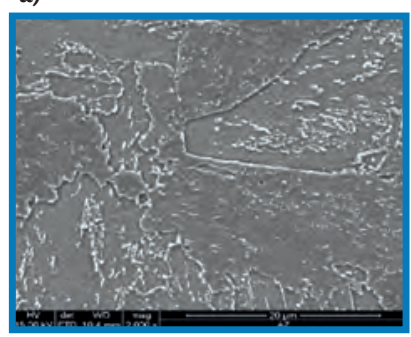

b)

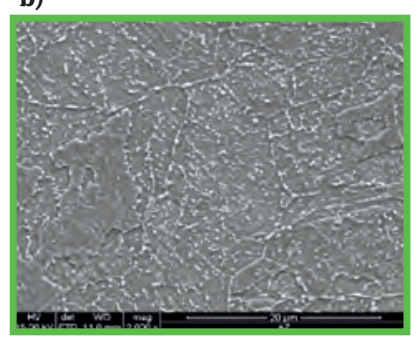

c)
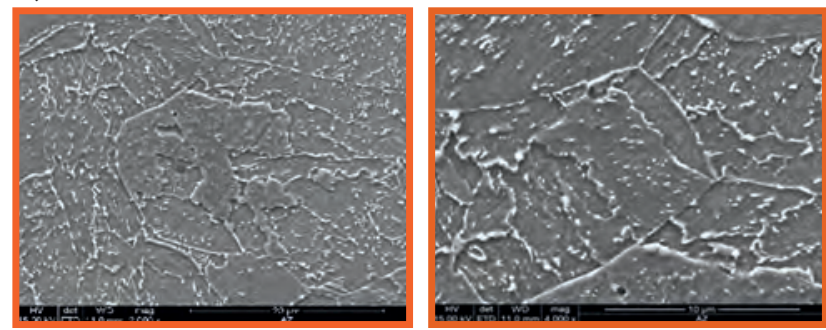

$18 \mathrm{~K} 360$

ID WP 2.1 K360, steel 21HMF, hardness 210 HV10

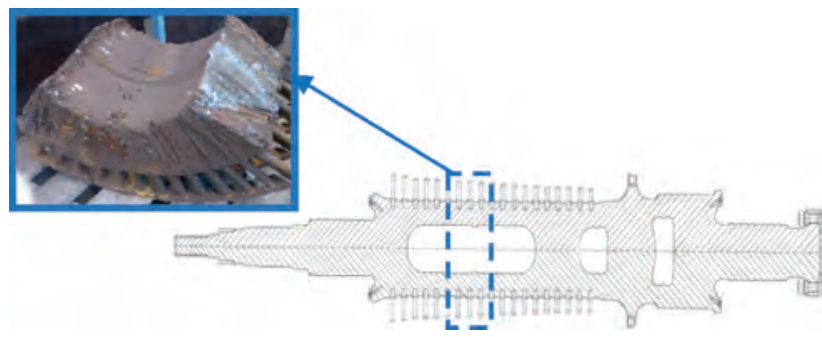

CLASS $2(I / I I, a, 0) ; t_{\mathrm{e}} / t_{\mathrm{r}}=$ approx. 0.3

d)

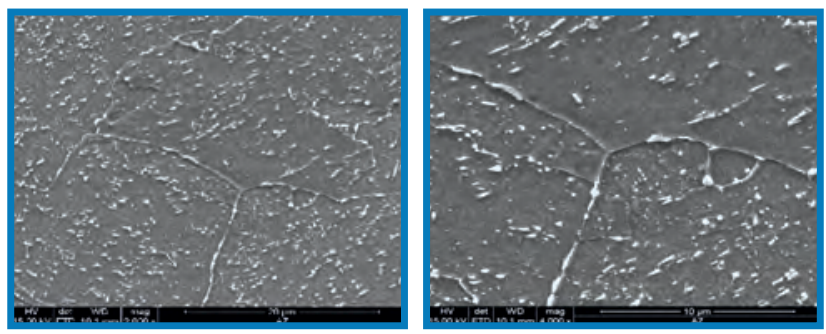

$18 \mathrm{~K} 360$

ID WP 3.1 K360, steel 21HMF, hardness 210 HV10

ID WP 3.4 K360, steel 21HMF, hardness 225 HV10

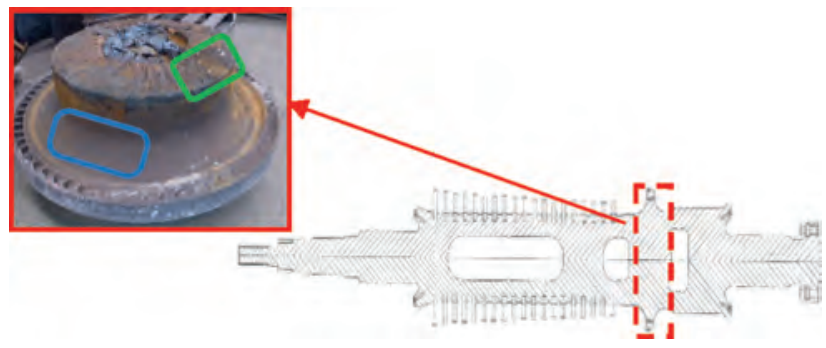

CLASS 2/3 (I/II, a/b, 0); $\mathrm{t}_{\mathrm{e}} / \mathrm{t}_{\mathrm{r}}=$ approx. 0.4

e)
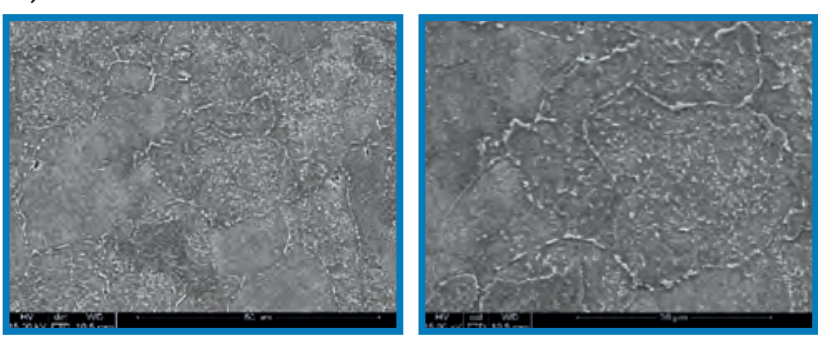

f)

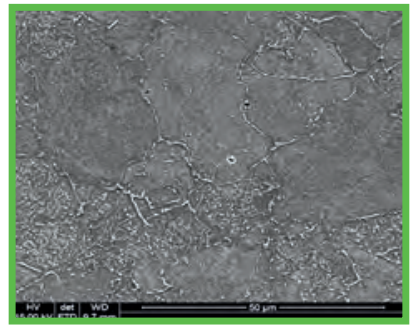

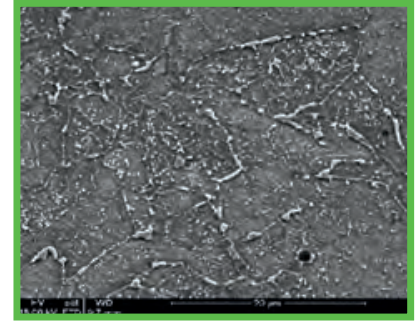

Fig. 5. Microstructure of the material of the $360 \mathrm{MW}$ unit $18 \mathrm{~K} 360$ turbine rotor WP high-pressure part after 220,000 operating hours observed on a crosswise microsection using a scanning electron microscope: a) in the area of rotor tip on the safety control side (ID WP 1.1 K360), b) in the area of rotor tip on the safety control side (ID WP 1.2 K360), c) in the area of rotor's bearing pin (ID WP $1.3 \mathrm{~K} 360$ ), d) in the drum in the region of stage 12-13 (ID WP 2.1 K360), e, f) in the steam inlet area in the control wheel region (ID WP 3.1K360, WP 3.4K360)

Rys. 5. Mikrostruktura materiału części wysokoprężnej WP wirnika turbiny $18 K 360$ bloku 360 MW po 220000 godzin eksploatacji obserwowana na zgładzie poprzecznym w skaningowym mikroskopie elektronowym: a) w obszarze końcówki wirnika od strony regulatora bezpieczeństwa (ozn. WP 1.1 K360), b) w obszarze końcówki wirnika od strony regulatora bezpieczeństwa (ozn. WP 1.2 K360), c) w obszarze czopa lożyskowego wirnika (ozn. WP 1.3 K360), d) w bębnie w rejonie 12-13 stopnia (ozn. WP 2.1 K360), e, f) w obszarze wlotu pary w rejonie koła regulacyjnego (ozn. WP 3.1K360, WP 3.4K360) 
the $200 \mathrm{MW}$ unit from the outer periphery of the disc of the first unregulated stage of the WP high-pressure part with a visible groove for fixing the blades after 200,000 operating hours are shown in Fig. 3 . The results of microstructure examination for the SP medium-pressure part of the $18 \mathrm{~K} 360$ turbine rotor after 220,000 operating hours in the material of the carrier thrust bearing pin (ID SP 1.1 K360), in the front part of the gland (ID SP $2.1 \mathrm{~K} 360$ ) and in the drum near the steam inlet (ID SP 3.1 K360) are shown in Fig. 4. The results of the studies of the microstructure of the WP high-pressure part of the $18 \mathrm{~K} 360$ turbine rotor after 220,000 operating hours in the material of the rotor tip from the safety regulator side (ID WP $1.1 \mathrm{~K} 360$ ), rotor end from the safety regulator side (ID WP $1.2 \mathrm{~K} 360$ ), rotor's bearing pin (ID WP $1.3 \mathrm{~K} 360$ ), in the drum in the region of stage
12-13 (ID WP $2.1 \mathrm{~K} 360$ ) and in the area of the steam inlet near the regulating wheel (ID WP $3.1 \mathrm{~K} 360$, WP $3.4 \mathrm{~K} 360$ ) is shown in Fig. 5.

For the proper assessment of the material condition, the classification of the structure condition was used with the corresponding degree of wear, which determine its degree of depletion. The assessment of the state of the structure was made in accordance with Łukasiewicz - IMŻ classification in the form of a designated structure class and the corresponding degree of wear based on the observation of the state of bainitic areas for the disclosed ferritic-bainitic structure, the degree of development of precipitation processes and the state of internal damage [1, 2]. The description of the structure's condition and the assessment result are presented in Table 2.

Table 2. Results of microstructure examination on etched microsections of WP part material of TK200 steam turbine rotor after approx. 200,000 operating hours and SP and WP parts of steam turbine rotor of the $18 \mathrm{~K} 360$ unit after 220,000 operating hours, made of $21 \mathrm{HMF}$ steel; assigned structural class, corresponding degree of wear and hardness

Tabela 2. Wyniki badań mikrostruktury na trawionych zgładach metalograficznych materiału części WP wirnika turbiny parowej TK200 po ok. 200000 godzin eksploatacji oraz części SP i WP wirnika turbiny parowej bloku 18K360 po 220000 godzin eksploatacji wykonanych ze stali 21HMF, wyznaczona klasa struktury, odpowiadający jej stopień wyczerpania i twardość

\begin{tabular}{|c|c|c|c|c|}
\hline $\begin{array}{c}\text { Component type / } \\
\text { Fig. }\end{array}$ & $\begin{array}{c}\text { Operating } \\
\text { parameters } \\
T_{\mathrm{r}},\left[{ }^{\circ} \mathrm{C}\right] \\
\underline{\sigma}_{\mathbf{r}}[\mathrm{MPa}] \\
\text { operating } \\
\text { time, }[\mathrm{h}] \\
\end{array}$ & Microstructure description & $\begin{array}{l}\text { Structural class, } \\
\text { degree of wear }\end{array}$ & $\begin{array}{c}\text { HV } \\
\text { hardness }\end{array}$ \\
\hline $\begin{array}{l}\text { WP high-pressure part } \\
\text { of } 200 \text { MW unit rotor } \\
\text { outer disc periphery of } \\
\text { the first uncontrolled } \\
\text { stage } \\
\text { (ID WP.TK200) } \\
\text { Fig. } 3\end{array}$ & $\begin{array}{c}500 \\
\underline{14.80} \\
200,000\end{array}$ & $\begin{array}{l}\text { Bainitic-ferritic structure. Bainite with sparse areas of ferrite. Partial } \\
\text { or significant disappearance of bainitic areas with a significantly } \\
\text { advanced precipitation process. Numerous precipitates inside } \\
\text { bainitic areas and on grain boundaries, forming chains. } \\
\text { The initiation of internal damage processes was not observed. } \\
\text { No discontinuities and microcracks were observed in the structure. }\end{array}$ & $\begin{array}{c}(\mathrm{I}, \mathrm{a} / \mathrm{b}, \mathrm{O})^{1)} \\
t_{\mathrm{e}} / t_{\mathrm{r}}=\text { appsS 2/3 } \\
\text { approx. } 0.4\end{array}$ & 195 \\
\hline $\begin{array}{l}\text { SP medium-pressure } \\
\text { part of } 360 \text { MW unit } \\
\text { rotor } \\
\text { carrier thrust bearing } \\
\text { pin } \\
\text { (ID SP } 1.1 \mathrm{~K} 360) \\
\text { Fig. } 4 \mathrm{a}\end{array}$ & $\begin{array}{c}40 \\
\underline{0} \\
220,000\end{array}$ & $\begin{array}{l}\text { Bainitic-ferritic structure. Bainite with few ferrite grains and } \\
\text { numerous precipitates inside bainite. Image of microstructure } \\
\text { similar to the typical microstructure of the initial state of the rotor } \\
\text { material made of the tested steel. } \\
\text { The initiation of internal damage processes was not observed. } \\
\text { No discontinuities and microcracks were observed in the structure. }\end{array}$ & $\begin{array}{l}\frac{(0, \mathrm{o}, \mathrm{O})^{1)}}{\text { CLASS O }} \\
t_{\mathrm{e}} / t_{\mathrm{r}}=0\end{array}$ & 240 \\
\hline $\begin{array}{l}\text { SP medium-pressure } \\
\text { part of } 360 \text { MW unit } \\
\text { rotor } \\
\text { in the front of the gland } \\
\quad \text { (ID SP } 1.2 \mathrm{~K} 360 \text { ) } \\
\text { Fig. } 4 \mathrm{~b}\end{array}$ & $\begin{array}{c}240 \\
\underline{0} \\
220,000\end{array}$ & $\begin{array}{l}\text { Bainitic-ferritic structure. Bainite with numerous, mostly fine } \\
\text { precipitates. Image of microstructure similar to the typical } \\
\text { microstructure of the initial state of the rotor material made of the } \\
\text { tested steel. } \\
\text { The initiation of internal damage processes was not observed. } \\
\text { No discontinuities and microcracks were observed in the structure. }\end{array}$ & $\begin{array}{l}(0, \mathrm{o}, \mathrm{O})^{1)} \\
\frac{\text { CLASS O }}{t_{\mathrm{e}} / t_{\mathrm{r}}=0}\end{array}$ & 242 \\
\hline $\begin{array}{l}\text { SP medium-pressure } \\
\text { part of } 360 \text { MW unit } \\
\text { rotor } \\
\text { rotor's SP part drum } \\
\text { section in steam inlet } \\
\text { area } \\
\text { (ID SP } 2.1 \mathrm{~K} 360 \text { ) } \\
\text { Fig. } 4 \mathrm{c}\end{array}$ & $\begin{array}{c}535 \\
\underline{3.93} \\
220,000\end{array}$ & $\begin{array}{l}\text { Bainitic structure with sparse ferrite grains. The material is } \\
\text { characterised by bainite lamellae with numerous precipitates } \\
\text { on lamellae boundaries and inside them. Precipitates, locally } \\
\text { forming chains, were observed on bainite lamellae boundaries. } \\
\text { Also inside these areas, a significant number of precipitates were } \\
\text { revealed, which can be identified by their morphological features: } \\
\text { finely-dispersed as VC precipitates and small elongated as } \mathrm{Mo}_{2} \mathrm{C} \text {. } \\
\text { In addition, } \mathrm{M}_{3} \mathrm{C} \text { cementite in the form of larger precipitates were } \\
\text { observed in these areas. } \\
\text { The initiation of internal damage processes was not observed. } \\
\text { No discontinuities and microcracks were observed in the structure. }\end{array}$ & $\begin{array}{c}(0 / \mathrm{I}, \mathrm{O} / \mathrm{a}, \mathrm{O})^{1)} \\
\quad \underline{\text { CLASS } 1} \\
t_{\mathrm{e}} / t_{\mathrm{r}}=\text { approx. } 0.2\end{array}$ & 247 \\
\hline $\begin{array}{l}\text { WP high-pressure part } \\
\text { of } \mathbf{3 6 0} \text { MW unit rotor } \\
\text { rotor tip on safety } \\
\text { control side } \\
\text { (ID WP } 1.1 \mathrm{~K} 360 \text { ) } \\
\text { Fig. } 5 \mathrm{a}\end{array}$ & $\begin{array}{c}\mathrm{RT} \\
\underline{0} \\
220,000\end{array}$ & $\begin{array}{l}\text { Bainitic-ferritic structure. Bainite lamellae with numerous fine } \\
\text { precipitates. Image of microstructure similar to the typical } \\
\text { microstructure of the initial state of the rotor material made of the } \\
\text { tested steel. } \\
\text { The initiation of internal damage processes was not observed. } \\
\text { No discontinuities and microcracks were observed in the structure. }\end{array}$ & $\begin{array}{l}(0, \mathrm{o}, \mathrm{O})^{1)} \\
\frac{\text { CLASS O }}{t_{\mathrm{e}} / t_{\mathrm{r}}=0}\end{array}$ & 244 \\
\hline $\begin{array}{l}\text { WP high-pressure part } \\
\text { of } \mathbf{3 6 0} \text { MW unit rotor } \\
\text { rotor tip on safety } \\
\text { control side } \\
\text { (ID WP } 1.2 \mathrm{~K} 360) \\
\text { Fig. } 5 \mathrm{~b}\end{array}$ & $\begin{array}{c}286 \\
\underline{0} \\
220,000\end{array}$ & $\begin{array}{l}\text { Bainitic-ferritic structure. Dominating bainite with numerous, } \\
\text { rather fine, precipitates. The occurrence of precipitates at the } \\
\text { boundaries of bainite lamellae was observed, which may make this } \\
\text { material different than the typical rotor material in the initial state } \\
\text { The initiation of internal damage processes was not observed. } \\
\text { No discontinuities and microcracks were observed in the structure. }\end{array}$ & $\begin{array}{c}(0, \mathrm{o}, \mathrm{O})^{1)} \\
t_{\mathrm{e}} / t_{\mathrm{r}}=\operatorname{appsS} \mathrm{appox} .0\end{array}$ & 238 \\
\hline
\end{tabular}




\begin{tabular}{|c|c|c|c|c|}
\hline $\begin{array}{c}\text { Component type / } \\
\text { Fig. }\end{array}$ & $\begin{array}{c}\text { Operating } \\
\text { parameters } \\
T_{\mathrm{v}}\left[{ }^{\circ} \mathrm{C}\right] \\
\sigma_{\mathrm{r}}[\mathrm{MPa}] \\
\text { operating } \\
\text { time, }[\mathrm{h}]\end{array}$ & Microstructure description & $\begin{array}{l}\text { Structural class, } \\
\text { degree of wear }\end{array}$ & $\begin{array}{c}\text { HV } \\
\text { hardness }\end{array}$ \\
\hline $\begin{array}{l}\text { WP high-pressure part } \\
\text { of } \mathbf{3 6 0} \text { MW unit rotor } \\
\text { rotor's bearing pin } \\
\text { (ID WP } 1.3 \mathrm{~K} 360 \text { ) } \\
\text { Fig. } 5 \mathrm{c}\end{array}$ & $\begin{array}{c}398 \\
\underline{0} \\
220,000\end{array}$ & $\begin{array}{l}\text { Bainitic-ferritic structure. Bainite with few ferrite grains and } \\
\text { numerous precipitates inside bainite. Image of microstructure } \\
\text { similar to the typical microstructure of the initial state of the rotor } \\
\text { material made of the tested steel. } \\
\text { The initiation of internal damage processes was not observed. } \\
\text { No discontinuities and microcracks were observed in the structure }\end{array}$ & $\begin{array}{l}\frac{(0,0,0)^{1)}}{\text { CLASS O }^{2}} \\
t_{\mathrm{e}} / t_{\mathrm{r}}=\text { approx. } 0\end{array}$ & 235 \\
\hline $\begin{array}{l}\text { WP high-pressure part } \\
\text { of } \mathbf{3 6 0} \text { MW unit rotor } \\
\text { drum fragment within } \\
\text { the region of stage 12-13 } \\
\quad \text { (ID WP 2.1 K360) } \\
\quad \text { Fig. 5d }\end{array}$ & $\begin{array}{c}510 \\
\underline{14.2} \\
220,000\end{array}$ & $\begin{array}{l}\text { Bainitic-ferritic structure. The material is characterised by a partial } \\
\text { atrophy of lamellae and numerous precipitates on plate boundaries } \\
\text { and inside them. Chain-forming precipitates, probably of the } \\
\text { chromium-rich } \mathrm{M}_{7} \mathrm{C}_{3} \text { carbide, were observed at the boundaries } \\
\text { of bainite lamellae. Also inside these areas, a significant number } \\
\text { of precipitates were revealed, which can be identified by } \\
\text { their morphological features as finely-dispersed VC and } \mathrm{Mo}_{2} \mathrm{C} \\
\text { precipitates. They are clearly larger than in the other examined } \\
\text { areas of the rotor's WP part. The partial atrophy of bainite lamellae } \\
\text { is confirmed by the lower hardness. } \\
\text { The initiation of internal damage processes was not observed. } \\
\text { No discontinuities and microcracks were observed in the structure. }\end{array}$ & $\begin{array}{c}(\mathrm{I} / \mathrm{II}, \mathrm{a}, \mathrm{O})^{1)} \\
\text { CLASS 2 } \\
t_{\mathrm{e}} / t_{\mathrm{r}}=\text { approx. } \\
0.3-0.4\end{array}$ & 210 \\
\hline $\begin{array}{l}\text { WP high-pressure part } \\
\text { of } 360 \mathrm{MW} \text { unit rotor } \\
\text { steam inlet area } \\
\text { in the regulatory wheel } \\
\text { region } \\
\text { (ID WP } 3.1 \mathrm{~K} 360 \text {, WP } \\
3.4 \mathrm{~K} 360 \text { ) } \\
\text { Fig. } 5 \mathrm{e}, \mathrm{f}\end{array}$ & $\begin{array}{c}535 \\
\underline{17.1} \\
220,000\end{array}$ & $\begin{array}{l}\text { Bainite with sparse areas of ferrite. Bainitic areas with a significant } \\
\text { disappearance of bainite lamellae are characterised by an advanced } \\
\text { precipitation process, which is evidenced by numerous precipitates } \\
\text { inside these areas. Based on their morphological features, it can } \\
\text { be assumed that these are fine spheroidal precipitates of the } \\
\text { vanadium-rich } \mathrm{MC} \text { carbide and elongated precipitates of the } \\
\text { molybdenum-rich } \mathrm{M}_{2} \mathrm{C} \text { carbide. The chain-forming precipitates } \\
\text { that occur at the boundaries of these regions are likely precipitates } \\
\text { of chromium-rich } \mathrm{M}_{23} \mathrm{C}_{6} \text { carbide. No significant differences were } \\
\text { observed in the microstructure image on the cross-section from the } \\
\text { surface to the rotor's core. } \\
\text { The initiation of internal damage processes was not observed. } \\
\text { No discontinuities and microcracks were observed in the structure }\end{array}$ & $\begin{array}{c}(\mathrm{I} / \mathrm{II}, \mathrm{a} / \mathrm{b}, \mathrm{O}) \\
\text { CLASS 2/3 } \\
t_{\mathrm{e}} / t_{\mathrm{r}}=\text { approx. } 0.4\end{array}$ & 211 \\
\hline
\end{tabular}

Notes: ${ }^{1)} \mathrm{I}$ - bainite disintegration class, a - development status class of carbide precipitation processes, $\mathrm{O}$ - development status class of internal damage processes

After approx. 200,000 operating hours, the material of the WP high-pressure part of the 21HMF steel steam turbine rotor of the $200 \mathrm{MW}$ power unit, taken from the area of the outer periphery of the disc of the first unregulated stage of this part of the rotor, where the operating temperature is $530^{\circ} \mathrm{C}$, is characterised by bainite with sparse ferrite grains and numerous precipitates at the boundaries of bainite lamellae and inside them. A partial atrophy of bainite lamellae can be observed in the examined area's material. The lower hardness of 195 HV10 confirms the partial atrophy of bainite lamellae. An evidence of the significant advancement of the precipitation process are numerous precipitates of different sizes inside these areas, and fine or small spheroidal precipitates, including MC carbides rich in vanadium. Chain-forming precipitates, probably of the chromium-rich $\mathrm{M}_{23} \mathrm{C}_{6}$ carbide, were observed at the boundaries of bainite lamellae. Moreover, inside these regions, a significant amount of precipitates was revealed, which, due to their morphological features, can be identified as $\mathrm{Mo}_{2} \mathrm{C}$, larger and irregularly shaped - as $\mathrm{M}_{6}$ C. (Fig. 3).

The material of the SP medium-pressure part of the $21 \mathrm{HMF}$ steel rotor of the steam turbine of the $360 \mathrm{MW}$ power unit after approx. 220,000 operating hours, taken from the carrier thrust bearing pin (ID SP 1.1) of the part of the rotor, where the operating temperature corresponds to the room temperature and amounts to approx. $40^{\circ} \mathrm{C}$ and the front part of the gland (ID SP 1.2) where the operating temperature is about $240^{\circ} \mathrm{C}$, is characterised by bainite with numerous precipitates. The image of the microstructure of these areas of the rotor is similar to the typical micro- structure of the initial state of the rotor material made of the tested steel. Based on the morphological features, it can be concluded that the dominant secondary phases are iron-rich $\mathrm{M}_{3} \mathrm{C}$ carbides and chromium-rich $\mathrm{M}_{7} \mathrm{C}_{3}$ carbides. Moreover, in the phase composition, there are numerous small MC precipitates rich in vanadium, as well as $\mathrm{M}_{2} \mathrm{C}$ carbides rich in molybdenum (Fig. $4 \mathrm{a}, \mathrm{b}$ ), the proportion of which is relatively small. The image of the structure and the state of development of precipitation processes correlate with the level of hardness of approx. 235 HV10 corresponding to the initial condition of the rotor made of 21HMF steel.

After approx. 220,000 operating hours, the material of the SP medium-pressure part of the $21 \mathrm{HMF}$ steel steam turbine rotor of the $360 \mathrm{MW}$ power unit, taken from a drum section of the SP part rotor in the steam inlet region (ID SP 2.1) of this rotor part, where the operating temperature is $535^{\circ} \mathrm{C}$, is characterised by bainite with quite numerous precipitates at the boundaries of lamellae and inside them (Fig. 4c). Preserved bainite lamellae can be observed in the examined area's material. Chain-forming precipitates of the chromium-rich $\mathrm{M}_{7} \mathrm{C}_{3}$ carbide were observed at the boundaries of bainite lamellae. Also inside these regions, a significant number of fine precipitates were revealed, which by their morphological features can be identified as vanadium-rich $\mathrm{MC}$ precipitates, $\mathrm{M}_{3} \mathrm{C}$ cementite precipitates of a significant size and small, elongated (disc) molybdenum-rich $\mathrm{M}_{2} \mathrm{C}$ precipitates. The image of the structure corresponds to the level of hardness which does not differ from the characteristic for the initial state and amounts to 
approx. 235 HV10. In this material, after such a long use at the temperature above the limit, the initiation of internal damage processes was not revealed.

The material of the WP high-pressure part of the $21 \mathrm{HMF}$ steel steam turbine rotor of the $360 \mathrm{MW}$ power unit after approx. 220,000 operating hours, taken from the end of the rotor from the safety regulator side (ID WP 1.1, WP 1.2) of the part of the rotor, where the operating temperature corresponds to a correspondingly similar to room temperature and amounting to $286^{\circ} \mathrm{C} s$ characterised by bainite with quite numerous precipitates. The image of the microstructure of the rotor tip material is similar to the typical microstructure of the initial state of the rotor material made of the tested steel (Fig. 5a, b). The precipitates present in the structure are mainly $\mathrm{M}_{3} \mathrm{C}$ cementite and numerous fine vanadium-rich MC particles, as well as a small amount of molybdenum-rich $\mathrm{M}_{2} \mathrm{C}$ carbides.

After approx. 220,000 operating hours, the material of the WP high-pressure part of the 21HMF steel steam turbine rotor of the $360 \mathrm{MW}$ power unit, taken from a drum section from the area of 12-13th stage (ID WP 2.1) of the rotor part, where the operating temperature is $510^{\circ} \mathrm{C}$, is characterised by bainite with numerous precipitates at the boundaries of lamellae and inside them (Fig. 5d). A partial atrophy of bainite lamellae can be observed in the examined area's material. Precipitates of the chromium-rich $\mathrm{M}_{7} \mathrm{C}_{3}$ carbide, forming chain systems, were observed at the boundaries of bainite lamellae. Moreover, a considerable amount of dispersed precipitates, vanadium-rich MC type carbides and $\mathrm{M}_{2} \mathrm{C}$ molybdenum carbides were revealed within these regions. Their geometric features are relatively larger than in the other examined areas of the rotor's WP part. The partial atrophy of bainite lamellae is also confirmed by the lower hardness. Despite such a long use at the temperature above the limit, the initiation of internal damage processes was not revealed in the material.

After approx. 220,000 operating hours, the material of the WP high-pressure part of the $21 \mathrm{HMF}$ steel steam turbine rotor of the $360 \mathrm{MW}$ power unit, taken from the steam inlet area within the control wheel region (ID WP 3.1) of this rotor part, where the operating temperature is $535^{\circ} \mathrm{C}$, is characterised by bainite with numerous precipitates at the boundaries of lamellae and inside them (Fig. 5e). A significant atrophy of bainite lamellae can be observed in the examined area's material. Chain-forming precipitates, probably of the $\mathrm{M}_{7} \mathrm{C}_{3}$ carbide, were observed at the boundaries of bainite lamellae. Within these regions, a considerable amount of $\mathrm{M}_{3} \mathrm{C}$ cementite coagulated precipitates and $\mathrm{MC}$ fine precipitates, as well as a small proportion of molybdenum-rich $\mathrm{M}_{2} \mathrm{C}$ carbides, were observed. The phase composition determined in X-ray studies, including their type and relative content, confirms a significant degree of

Table 3. Results of X-ray qualitative phase analysis of the deposit of electrolytically isolated material precipitates of the tested sections of the WP part of the TK200 unit turbine rotor after 200,000 hours of operation, and the SP and WP parts of the $18 \mathrm{~K} 360$ unit turbine rotor after 220,000 hours of operation

Tabela 3. Wyniki rentgenowskiej jakościowej analizy fazowej osadu wyizolowanych elektrolitycznie wydzieleń materiału badanych wycinków części WP wirnika turbiny bloku TK200 po 200000 godzin eksploatacji oraz części SP i WP wirnika turbiny bloku $18 K 360$ po 220000 godzin eksploatacji

\begin{tabular}{|c|c|c|c|}
\hline Tested component & Tested material & $\begin{array}{c}\text { Identified phase components and } \\
\text { their relative content }\end{array}$ & $\begin{array}{c}\text { Precipitate } \\
\text { development degree } \\
\text { class } \\
\text { Degree of wear } t_{\mathrm{e}} / t_{\mathrm{r}}\end{array}$ \\
\hline $\begin{array}{l}\text { WP high-pressure part of TK200 } \\
\text { turbine rotor after } \\
\text { approx. } 200,000 \\
\text { operating hours }\end{array}$ & $\begin{array}{l}\text { outer disc periphery of the first } \\
\text { uncontrolled stage } \\
\text { (ID WP.TK200) } \\
\text { made of 21HMF steel }\end{array}$ & $\begin{array}{l}\mathrm{Cr}_{7} \mathrm{C}_{3}-\text { main phase } \\
\mathbf{F e}_{3} \mathrm{C}-\text { main phase } \\
\mathrm{Mo}_{2} \mathrm{C}-\text { high } \\
\mathrm{VC}-\text { medium } \\
\mathrm{Cr}_{23} \mathrm{C}_{6}-\text { low } \\
\mathrm{Mo}_{3} \mathrm{Fe}_{3} \mathrm{C}-\text { low } \\
\mathrm{Fe}_{23} \mathrm{C}_{6} \text { - trace amount }\end{array}$ & $\frac{\text { class } \mathbf{a} / \mathrm{b}}{\text { approx. } 0.4}$ \\
\hline \multirow{2}{*}{$\begin{array}{l}\text { SP medium-pressure part of } \\
18 \mathrm{~K} 360 \text { turbine rotor } \\
\text { after approx. } 220,000 \\
\text { operating hours }\end{array}$} & $\begin{array}{l}\text { carrier thrust bearing pin } \\
\text { (ID SP } 1.1 \mathrm{~K} 360 \text { ) } \\
\text { made of } 21 \mathrm{HMF} \text { steel }\end{array}$ & $\begin{array}{l}\mathbf{M}_{3} \mathbf{C}-\text { main phase } \\
\mathbf{M}_{7} \mathbf{C}_{3}-\text { main phase } \\
\mathrm{M}_{2} \mathrm{C}-\text { high } \\
\mathrm{VC}-\text { medium } \\
\mathrm{MC}-\text { medium } \\
\end{array}$ & $\frac{\text { class o }}{0}$ \\
\hline & $\begin{array}{l}\text { rotor's SP part drum section in steam } \\
\text { inlet area } \\
\text { (ID SP } 2.1 \mathrm{~K} 360 \text { ) } \\
\text { made of } 21 \mathrm{HMF} \text { steel }\end{array}$ & $\begin{array}{l}\mathbf{M}_{3} \mathbf{C}-\text { main phase } \\
\mathbf{M}_{7} \mathbf{C}_{3}-\text { main phase } \\
\mathrm{M}_{2} \mathrm{C}-\text { medium } \\
\mathrm{VC}-\text { medium } \\
\mathrm{MC}-\text { medium }\end{array}$ & $\begin{array}{c}\text { class } 0 / a \\
\operatorname{approx.~} 0.2\end{array}$ \\
\hline \multirow{3}{*}{$\begin{array}{l}\text { WP high-pressure part of } 18 \mathrm{~K} 360 \\
\text { turbine rotor } \\
\text { after approx. } 220,000 \\
\text { operating hours }\end{array}$} & $\begin{array}{l}\text { rotor tip on safety control side } \\
\text { (ID WP } 1.1 \mathrm{~K} 360 \text { ) } \\
\text { made of } 21 \mathrm{HMF} \text { steel }\end{array}$ & $\begin{array}{l}\mathbf{F e}_{3} \mathbf{C}-\text { main phase } \\
\mathrm{M}_{7} \mathrm{C}_{3}-\text { high } \\
\mathrm{VC}-\text { medium } \\
\mathrm{Mo}_{2} \mathrm{C}-\text { low }\end{array}$ & $\frac{\text { class o }}{0}$ \\
\hline & $\begin{array}{l}\text { drum fragment within the region } \\
\text { of stage } 12-13 \\
\text { (ID WP } 2.1 \text { K360) } \\
\text { made of } 21 \text { HMF steel }\end{array}$ & $\begin{array}{l}\mathbf{M}_{\mathbf{7}} \mathbf{C}_{3}-\text { main phase } \\
\mathrm{Fe}_{3} \mathrm{C}-\text { high } \\
\mathrm{Mo}_{2} \mathrm{C}-\text { high } \\
\mathrm{VC}-\text { medium } \\
\mathrm{MC}-\text { medium }\end{array}$ & $\begin{array}{c}\text { class a } \\
\text { approx. } 0.3\end{array}$ \\
\hline & $\begin{array}{l}\text { steam inlet area } \\
\text { in the regulatory wheel region } \\
\text { (ID WP } 3.1 \mathrm{~K} 360 \text { ) } \\
\text { made of } 21 \mathrm{HMF} \text { steel }\end{array}$ & $\begin{array}{l}\mathbf{M}_{\mathbf{7}} \mathbf{C}_{\mathbf{3}}-\text { main phase } \\
\mathrm{Fe}_{3} \mathrm{C}-\text { high } \\
\mathrm{VC}-\text { medium } \\
\mathrm{MC}-\text { low } \\
\mathrm{Mo}_{2} \mathrm{C}-\text { low }\end{array}$ & 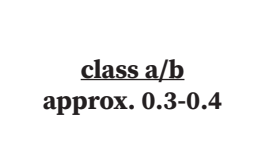 \\
\hline
\end{tabular}


changes in this respect as a result of long-term operation (Table 4). In addition, the image of the structure and the state of development of precipitation processes correlate with the hardness level of approx. 210 HV10, which is approx. 30 units lower than the hardness characteristic for the initial state. Also in this material, despite such a long use at the temperature significantly above the limit, the initiation of internal damage processes was not revealed in the material.

\subsection{X-RAY ANALYSIS OF PHASE COMPOSITION OF PRECIPITATES}

The X-ray analysis of the phase composition of the precipitates was carried out on the precipitate obtained by dissolving the matrix using the electrolytic method of the material of the tested turbine rotor sections. The tests were performed with an Empyrean X-ray diffractometer using cobalt radiation in a configuration with a Pixcel detector. The obtained results of the X-ray diffraction analysis of the isolated carbide deposit allowed to reveal the types of precipitates occurring and to define their content in the tested materials, which is summarised in Table 3. Selected examples of the obtained diffraction patterns are shown in Fig. 6. The diffraction pattern of the precipitates from the material of the outer periphery of the disc of the first unregulated stage of the WP high-pressure part of the TK 200 turbine rotor of the $200 \mathrm{MW}$ unit after 200,000 operating hours is shown in Fig. 6a, while Fig. 6b illustrates the phase composition of the rotor tip material from the side of the safety regulator of the SP medium-pressure part, and Fig. $6 \mathrm{c}-$ from the area of the steam inlet in the area of the control wheel of the WP high-pressure part of the $360 \mathrm{MW}$ $18 \mathrm{~K} 360$ unit turbine rotor after 220,000 operating hours. Based on the obtained sequence of precipitates, the degree of development of precipitation processes in the tested low-alloy 21HMF steel was estimated in accordance with the own classification of Łukasiewicz - IMŻ [1, 2].

The state of development of the precipitation processes of the outer periphery of the disc of the first unregulated stage of the tested WP part (ID WP.TK200) of the rotor of the $200 \mathrm{MW}$ unit after long-term operation for 200,000 hours corresponds to class $\mathrm{a} / \mathrm{b}$ and the degree of wear $t_{\mathrm{e}} / t_{\mathrm{r}}=$ approx. 0.4. The state of development of the precipitation processes of the carrier thrust bearing pin material (ID SP 1.1K360) of the SP part of the $360 \mathrm{MW}$ unit rotor after long-term operation for approx. 220,000 hours corresponds to class $o$ and degree of wear $t_{\mathrm{e}} / t_{\mathrm{r}}=0$, i.e. the initial value of the tested 21HMF steel. The state of development of the precipitation processes of the rotor's SP part drum material in the steam inlet region (ID SP2.1 K360) of this rotor after long-term operation for approx. 220,000 hours corresponds to class o/a and the degree of wear $t_{\mathrm{e}} / t_{\mathrm{r}}=\mathrm{up}$ to 0.2 . The state of development of the precipitation processes of the rotor tip on the side of the safety regulator of the tested WP part (ID WP 1.1K360) of the $360 \mathrm{MW}$ unit rotor after long-term operation for approx. 220,000 hours corresponds to class o and degree of wear $t_{\mathrm{e}} / t_{\mathrm{r}}=0$, i.e. corresponds to the initial value of the tested $21 \mathrm{HMF}$ steel. The state of development
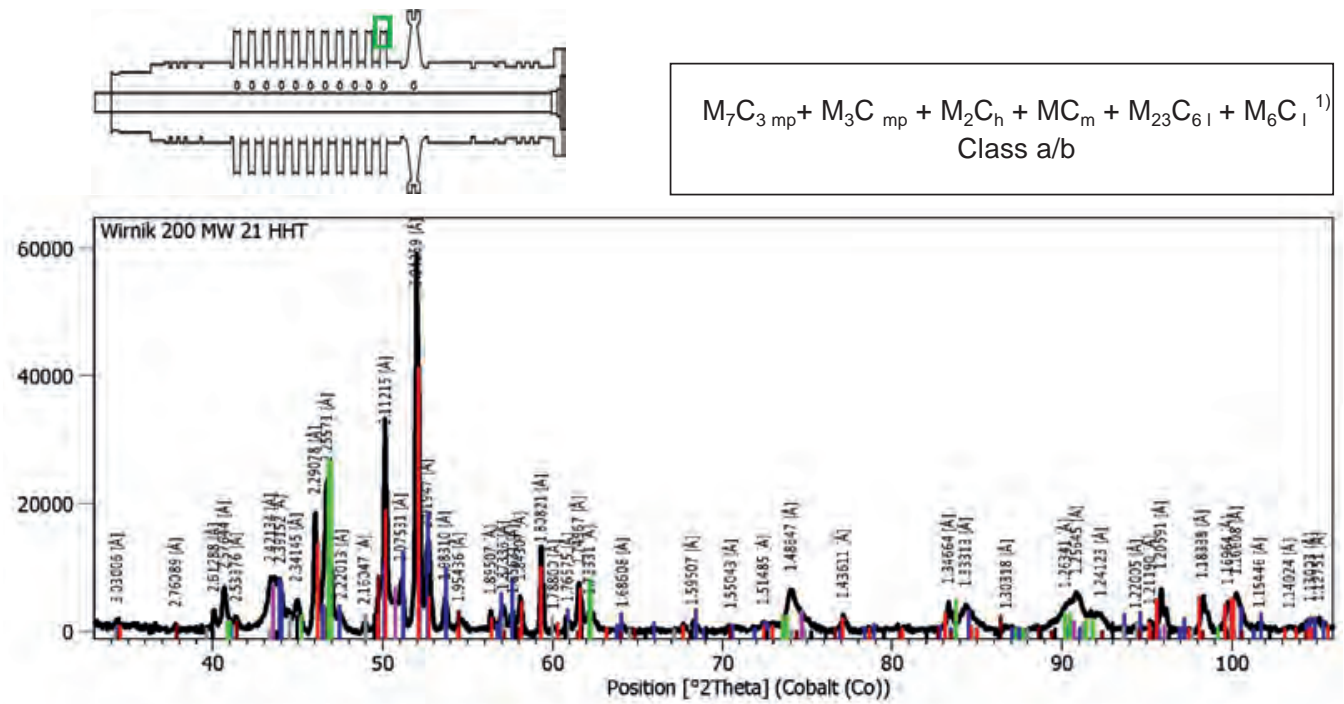

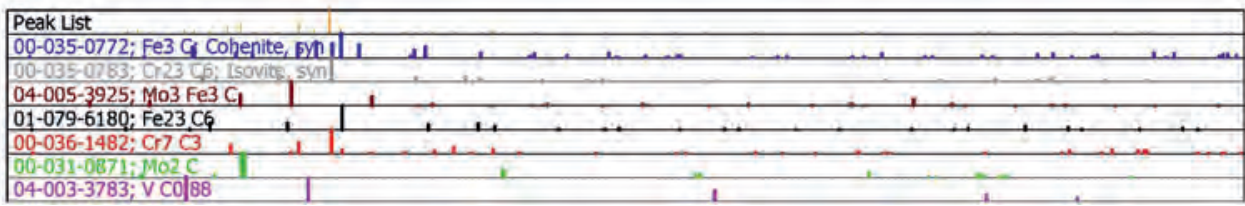

Fig. 6. Examples of X-ray diffraction patterns for isolates of material precipitates from sections of the tested parts of steam turbine rotors: a) of $200 \mathrm{MW}$ unit TK200 turbine WP high-pressure part after 200,000 operating hours, after 220,000 operating hours, along with the phase composition of precipitates and the estimated class of the degree of development of carbide precipitation processes in $21 \mathrm{HMF}$ steel after long-

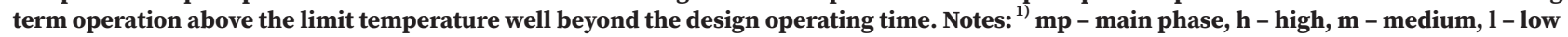
Rys. 6. Przykładowe dyfraktogramy rentgenowskie izolatów wydzieleń materiału wycinków badanych części wirników turbin parowych: a) cześci wysokopréżnej WP turbiny TK200 bloku 200 MW po 200 tys. godzin eksploatacji, , po 220 tys. godzin eksploatacji, wraz ze składem fazowym wydzieleń i oszacowaną klasą stopnia rozwoju procesów wydzieleniowych węglików w stali $21 \mathrm{HMF}$ po długotrwałej eksploatacji powyżej temperatury granicznej znacznie poza obliczeniowym czasem pracy. Uwagi: ${ }^{1)}$ f.gł. - faza główna, d. - dużo, śr. - średnio, m. - mało 


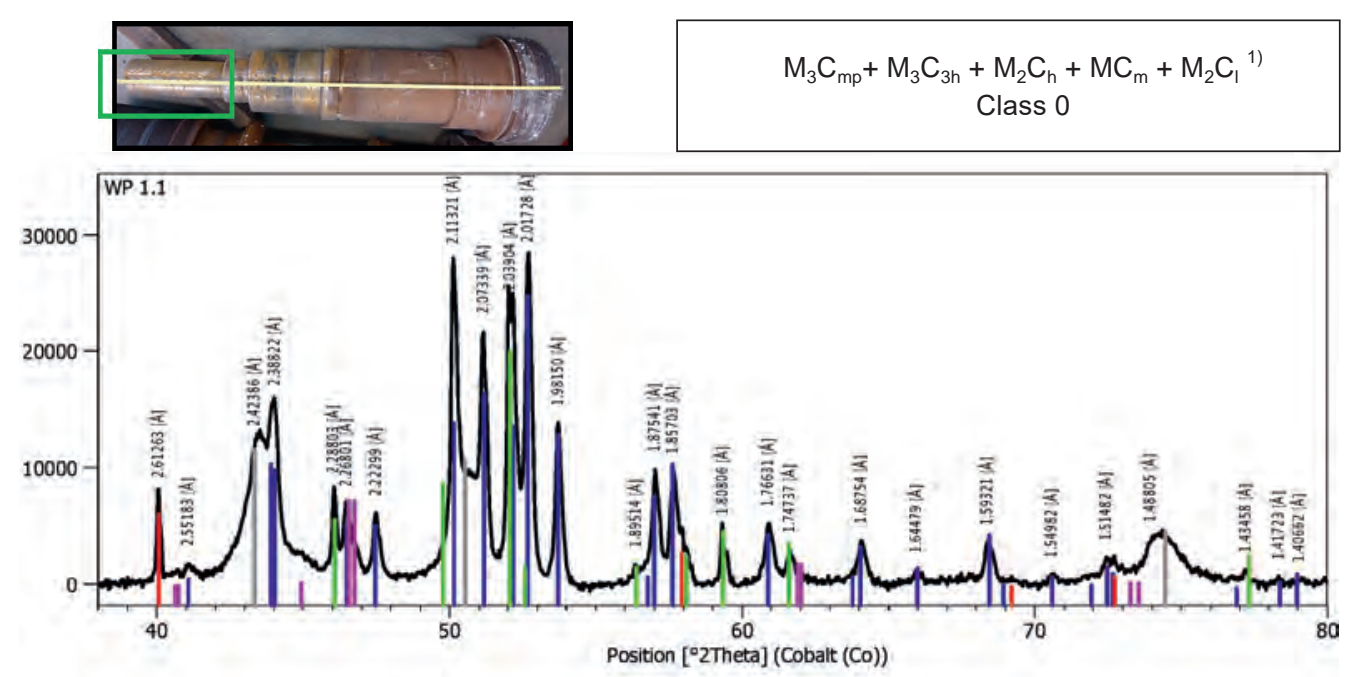

\begin{tabular}{|c|c|}
\hline Peak List & 1 \\
\hline 00-035-0772; Fe3 f; Cohenite, syn & 1 \\
\hline 04-003-3783; V [0.88 & $\perp$ \\
\hline 00-00;-0518; Mn +2 S; Alabandite, syn & 1 \\
\hline 00-022-0211: (Cr2.5 Fet, 3M00.1) G & \\
\hline 00-031-0871; Mo2 C & -1 \\
\hline
\end{tabular}
steam inlet area in the control wheel region (ID WP 3.1)

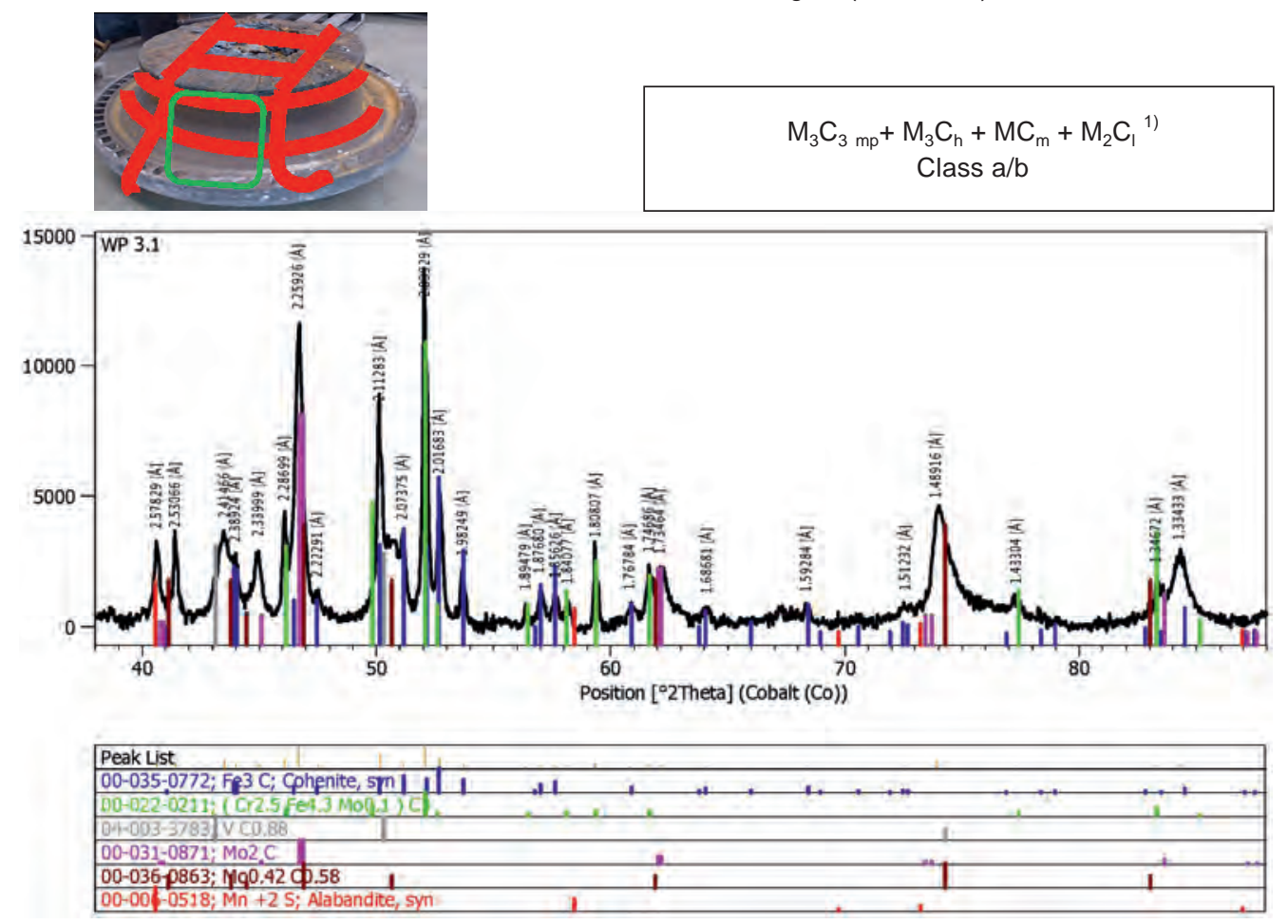

Fig. 6 cont. Examples of X-ray diffraction patterns for isolates of material precipitates from sections of the tested parts of steam turbine rotors: b) of $360 \mathrm{MW}$ unit 18K360 turbine SP medium-pressure part after 200,000 operating hours, c) of $360 \mathrm{MW}$ unit $18 \mathrm{~K} 360$ turbine WP high-pressure part after 220,000 operating hours, along with the phase composition of precipitates and the estimated class of the degree of development of carbide precipitation processes in 21HMF steel after long-term operation above the limit temperature well beyond the design operating time. Notes: ${ }^{1)} \mathrm{mp}$ - main phase, $\mathrm{h}$ - high, $\mathrm{m}$ - medium, 1 - low

Rys. 6 cd. Przykładowe dyfraktogramy rentgenowskie izolatów wydzieleń materiału wycinków badanych części wirników turbin parowych: b) części średnioprężnej SP turbiny18K360 bloku 360 MW po 220 tys. godzin eksploatacji, c) części wysokoprężnej WP turbiny18K360 bloku $360 \mathrm{MW}$ po 220 tys. godzin eksploatacji, wraz ze składem fazowym wydzieleń i oszacowaną klasą stopnia rozwoju procesów wydzieleniowych węglików w stali 21HMF po długotrwałej eksploatacji powyżej temperatury granicznej znacznie poza obliczeniowym czasem pracy. Uwagi: ${ }^{1)}$ f.gł. - faza główna, d. - dużo, śr. - średnio, m. - mało 
of the precipitation processes of the drum's material in the region of stage 12-13 of the tested WP part (ID WP2.1 K360) of the $360 \mathrm{MW}$ unit rotor after long-term operation for 220,000 hours corresponds to class a and the degree of wear $t_{\mathrm{e}} / t_{\mathrm{r}}=$ approx. 0.3 . The state of development of the precip- itation processes of the material in the seam inlet area in the region of the control wheel of the tested WP part (ID WP3.1 K360) of the $360 \mathrm{MW}$ unit rotor after long-term operation for 220,000 hours corresponds to class $\mathrm{a} / \mathrm{b}$ and the degree of wear $t_{\mathrm{e}} / t_{\mathrm{r}}=$ approx. 0.3-0.4.

Table 4. Test results for strength properties at room temperature and elevated temperature for sections of the SP medium-pressure and WP high-pressure part of the $21 \mathrm{HMF}$ steel $18 \mathrm{~K} 360$ turbine rotor after 220,000 hours of operation

Tabela 4. Wyniki badań właściwości wytrzymałościowych w temperaturze pokojowej i podwyższonej materiałów wycinków części średnioprężnej SP i wysokoprężnej WP wirnika turbiny $18 \mathrm{~K} 360$ po 220000 godzin eksploatacji wykonanych ze stali $21 \mathrm{HMF}$

\begin{tabular}{|c|c|c|c|c|c|c|}
\hline \multirow{2}{*}{$\frac{\text { Component name }}{\text { operating time }}$} & \multirow{2}{*}{$\frac{\text { Testing location }}{\text { identification }}$} & \multirow{2}{*}{$\begin{array}{c}\text { Testing } \\
\text { temperature } \\
T_{t},\left[{ }^{\circ} \mathrm{C}\right] \\
\end{array}$} & \multicolumn{4}{|c|}{ Strength properties } \\
\hline & & & $\begin{array}{c}\text { Tensile strength }^{1)} \\
\boldsymbol{R}_{\mathrm{m}}\left(\boldsymbol{R}_{\mathrm{m}}{ }^{\boldsymbol{t}}\right), \text { [MPa] }\end{array}$ & $\begin{array}{c}\text { Yield strength }{ }^{1)} \\
\boldsymbol{R}_{\mathbf{e}}\left(\boldsymbol{R}_{\mathbf{e}}^{\mathbf{t}}\right),[\mathbf{M P a}]\end{array}$ & $\begin{array}{c}\text { Elongation }^{1)} \\
\boldsymbol{A}_{5},[\%] \\
\end{array}$ & $\begin{array}{c}\text { Narrowing } \\
Z,[\%] \\
\end{array}$ \\
\hline \multirow{5}{*}{$\begin{array}{c}18 K 360 \\
\text { SP medium-pressure } \\
\text { part } \\
220,000 \text { operating } \\
\text { hours }\end{array}$} & \multirow{5}{*}{$\begin{array}{l}\text { carrier thrust } \\
\text { bearing pin } \\
\text { ID SP } 1.1 \mathrm{~K} 360\end{array}$} & 20 & $740 ; 740$ (min. 686) & 607; 606 (min. 588) & 19.4; 20.6 (min. 16) & $68 ; 67$ \\
\hline & & 200 & 667 & $544(\min .510)$ & 19.2 & 68 \\
\hline & & 300 & 649 & $536(\min .481)$ & 16.4 & 66 \\
\hline & & 450 & 588 & $483(\min .402)$ & 19.0 & 68 \\
\hline & & 500 & 541 & $470(\min .353)$ & 20.0 & 73 \\
\hline \multirow{10}{*}{$\begin{array}{c}18 K 360 \\
\text { SP medium-pressure } \\
\text { part } \\
\begin{array}{c}\text { 220,000 operating } \\
\text { hours }\end{array}\end{array}$} & \multirow{5}{*}{$\begin{array}{l}\text { place of embedding } \\
\text { of device } \\
\text { components for } \\
\text { rotor turning } \\
\text { ID SP } 1.2 \mathrm{~K} 360\end{array}$} & 20 & $751(\min .686)$ & $630.5(\min .588)$ & $20.3(\min .16)$ & 70 \\
\hline & & 200 & 680 & $570(\min .510)$ & 17.6 & 69 \\
\hline & & 300 & 671 & $563(\min .481)$ & 15.6 & 66 \\
\hline & & 450 & 600 & $511(\min .402)$ & 18.4 & 72 \\
\hline & & 500 & 550 & 497 (min. 353) & 17.2 & 76 \\
\hline & \multirow{5}{*}{$\begin{array}{l}\text { rotor's SP part drum } \\
\text { section in steam } \\
\text { inlet area } \\
\text { ID SP } 2.1 \mathrm{~K} 360\end{array}$} & 20 & $753 ; 760$ (min. 686) & $614 ; 619$ (min. 588) & $20.8 ; 21.4(\min .16)$ & $64 ; 66$ \\
\hline & & 200 & 679 & $556(\min .510)$ & 20.2 & 69 \\
\hline & & 300 & 659 & 538 (min. 481) & 16.8 & 64 \\
\hline & & 450 & 585 & 491 (min. 402) & 15.6 & 64 \\
\hline & & 500 & 532 & $463(\min .353)$ & 19.8 & 71 \\
\hline \multirow{20}{*}{$\begin{array}{c}18 \mathrm{~K} 360 \\
\text { WP high-pressure } \\
\text { part } \\
\text { 220,000 operating } \\
\text { hours }\end{array}$} & \multirow{5}{*}{$\begin{array}{l}\text { rotor tip on safety } \\
\text { control side } \\
\text { ID WP } 1.1 \mathrm{~K} 360\end{array}$} & 20 & $738 ; 740$ (min. 686) & $619 ; 621(588)$ & $20.4 ; 20.2(\min .16)$ & $70 ; 70$ \\
\hline & & 200 & 674 & $566(\min .510)$ & 17.8 & 69 \\
\hline & & 300 & 661 & $558(\min .481)$ & 16.2 & 67 \\
\hline & & 450 & 588 & 508 (min. 402) & 16.4 & 71 \\
\hline & & 500 & 543 & $484(\min .353)$ & 19.6 & 78 \\
\hline & \multirow{5}{*}{$\begin{array}{l}\text { place of embedding } \\
\text { of device } \\
\text { components for- } \\
\text { rotor turning } \\
\text { ID WP } 1.2 \mathrm{~K} 36 \text { ) }\end{array}$} & 20 & $750 ; 752$ (min. 686) & $629 ; 632(588)$ & $20.6(\min .16)$ & 71 \\
\hline & & 200 & 680 & $570(\min .510)$ & 17.6 & 69 \\
\hline & & 300 & 671 & $563(\min .481)$ & 15.6 & 66 \\
\hline & & 450 & 600 & $511(\min .402)$ & 18.4 & 72 \\
\hline & & 500 & 550 & $497\left(\min .353^{2)}\right)$ & 17.2 & 76 \\
\hline & \multirow{5}{*}{$\begin{array}{l}\text { drum fragment } \\
\text { within the region of } \\
\text { stage } 12-13 \\
\text { WP } 2.1 \mathrm{~K} 360\end{array}$} & 20 & $650 ; 650$ (min. 686) & $508 ; 507(588)$ & $22.4 ; 22.2(\min .16)$ & $72 ; 70$ \\
\hline & & 200 & 580 & $463(\min .510)$ & 20.0 & 71 \\
\hline & & 300 & 561 & $448(\min .481)$ & 18.2 & 70 \\
\hline & & 450 & 501 & 416 (min. 402) & 18.8 & 71 \\
\hline & & 500 & 459 & $398(\min .353)$ & 16.4 & 74 \\
\hline & \multirow{5}{*}{$\begin{array}{l}\text { steam inlet area } \\
\text { in the regulatory } \\
\text { wheel region } \\
\text { WP } 3.1 \text { K360 }\end{array}$} & 20 & 668;674 (min. 686) & $519 ; 538(\min .588)$ & 19.4; $20.0(\min .16)$ & $64 ; 66$ \\
\hline & & 200 & 589 & 444 (min. 510) & 17.2 & 64 \\
\hline & & 300 & 569 & $419(\min .481)$ & 17.2 & 59 \\
\hline & & 450 & 491 & 395 (min. 402) & 19.4 & 61 \\
\hline & & 500 & 436 & $357(\min .353)$ & 24.2 & 65 \\
\hline
\end{tabular}

\footnotetext{
1) ( ) minimum values according to the requirements for the material in its initial state according to PN-70 / H-94009 are stated in parentheses
} do not meet the requirements for the initial state 


\subsection{TEST ON STRENGTH PROPERTIES AT ROOM TEMPERATURE AND ELEVATED TEMPERATURE}

The studies on strength properties, i.e. tensile strength $R_{\mathrm{m}}$, yield strength $R_{\mathrm{e}}$, elongation $A_{5}$ and narrowing $Z$ were carried out at room temperature and at elevated temperature. The results of the tests of the materials of the SP medium-pressure and the WP high-pressure part of the $18 \mathrm{~K} 360$ turbine rotor after 220,000 hours of operation are summarised in Table 4, and the graphical form for the materials of the SP medium-pressure part is shown in Fig. 7, and for the materials of the WP high-pressure part - in Fig. 8.

The obtained results of tests of tensile strength and yield strength at room temperature of the material of all components of the SP medium-pressure part (ID SP 1.1, SP 1.2, SP 2.1) and the rotor ends on the side of the safety regulator (ID WP 1.1) and the place of embedding of the components of the rotor's turning device (marked WP 1.2) of the WP high-pressure part are higher than the minimum values required for the forgings of 21HMF steel turbine rotor shafts in the initial state in accordance with the PN-70 / H-94009 standard. The obtained elongation and narrowing values in the tensile test carried out at room temperature also meet the requirements of this standard. On the other hand, the obtained results of tests of tensile strength and yield point for the material from the drum area in the region of stage 12-13 (WP $2.118 \mathrm{~K} 360$ ) and the material from the steam inlet area in the region of the control wheel (WP 3.1 18K360) of the WP high-pressure part of the 21HMF steel $18 \mathrm{~K} 360$ turbine rotor do not meet the requirements at room and elevated temperature (columns 4 and 5 in Table 4).

\subsection{IMPACT STRENGTH TESTS AND DETERMINATION OF BRITTLE STATE TRANSITION TEMPERATURE}

The impact strength tests were carried out on samples with a V notch. A Mohr-Federhaff pendulum testing machine with a maximum impact energy of $294 \mathrm{~J}$ was used to break the samples. The results of the impact strength tests and the determined brittle transition temperature for the tested materials are summarised in Table 5 . The test temperature levels for individual material states were each time selected depending on the values of impact energy obtained at room temperature.

The obtained results of material impact tests for the tested parts of turbine rotors made of $21 \mathrm{HMF}$ steel do not meet the requirements for the initial state at room temperature and the expected minimum impact energy of $27 \mathrm{~J}$ for most of the tested rotor components. Selected examples in the form of a relationship between impact energy and testing temperature is presented in Fig. 9. In particular, Fig. 9a shows this relationship for the material of the outer periphery of the first stage of the unregulated rotor (ID WP.TK200) of the WP high-pressure part of the $200 \mathrm{MW}$ unit turbine rotor after 200,000 hours of operation, and in Fig. 9b - of the drum material in the region of the 12-13th stage of the WP high-pressure part of the $360 \mathrm{MW}$ unit turbine rotor after 220,000 operating hours.
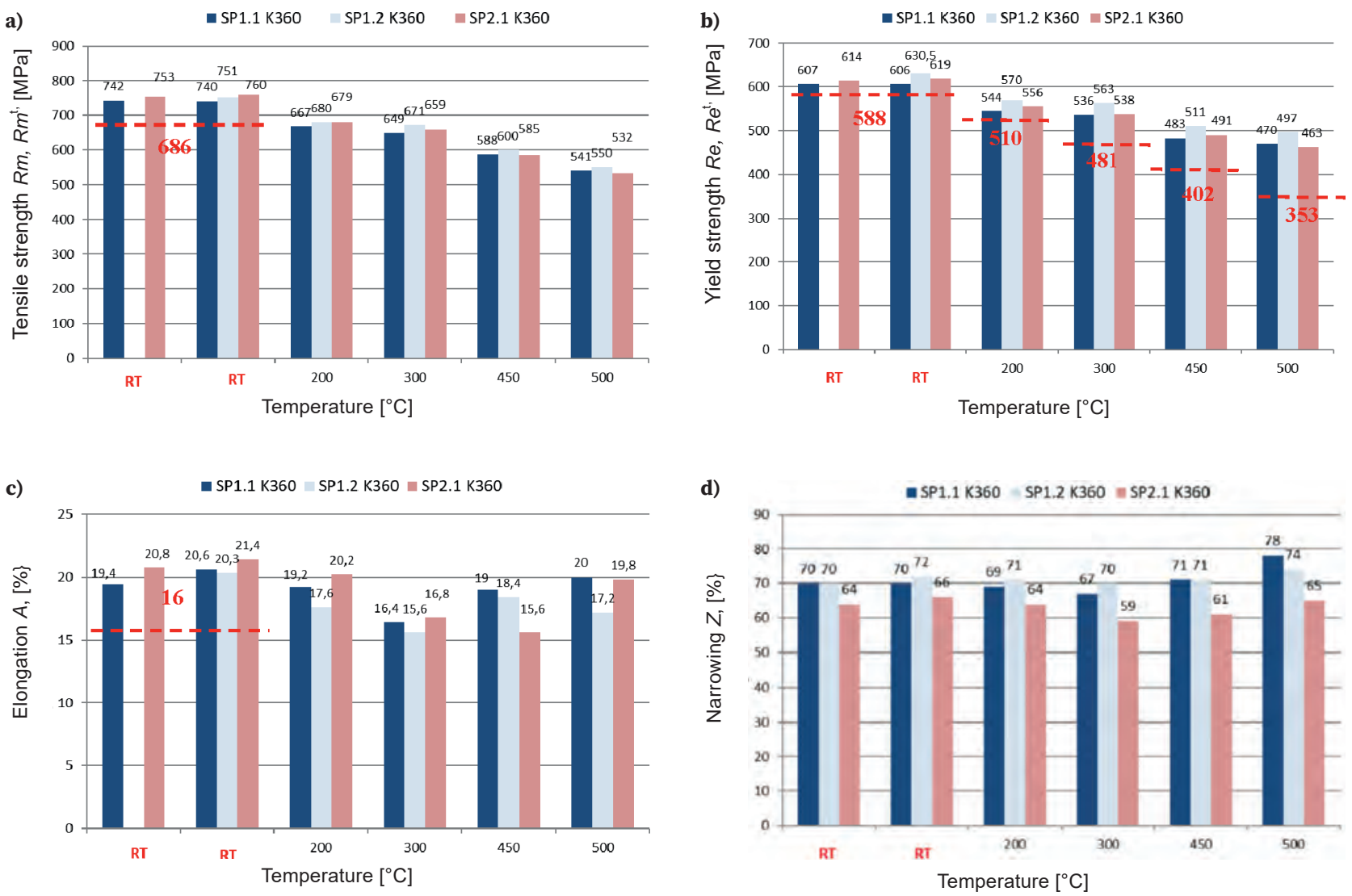

red marks the requirements for the material in the initial state

Fig. 7. Strength properties at room and elevated temperature for the material of the SP medium-pressure of the $18 \mathrm{~K} 360$ turbine rotor after 220,000 hours of operation: a) tensile strength, b) yield strength, c) elongation in tensile test, d) compression in tensile test

Rys. 7. Właściwości wytrzymałościowe w temperaturze pokojowej i podwyższonej materiału części średnioprężnej SP wirnika turbiny $18 K 360$ po 220000 godzin eksploatacji: a) wytrzymałość na rozciąganie, b) granica plastyczności, c) wydłużenie w próbie rozciągania, d) przewężenie w próbie rozciągania 

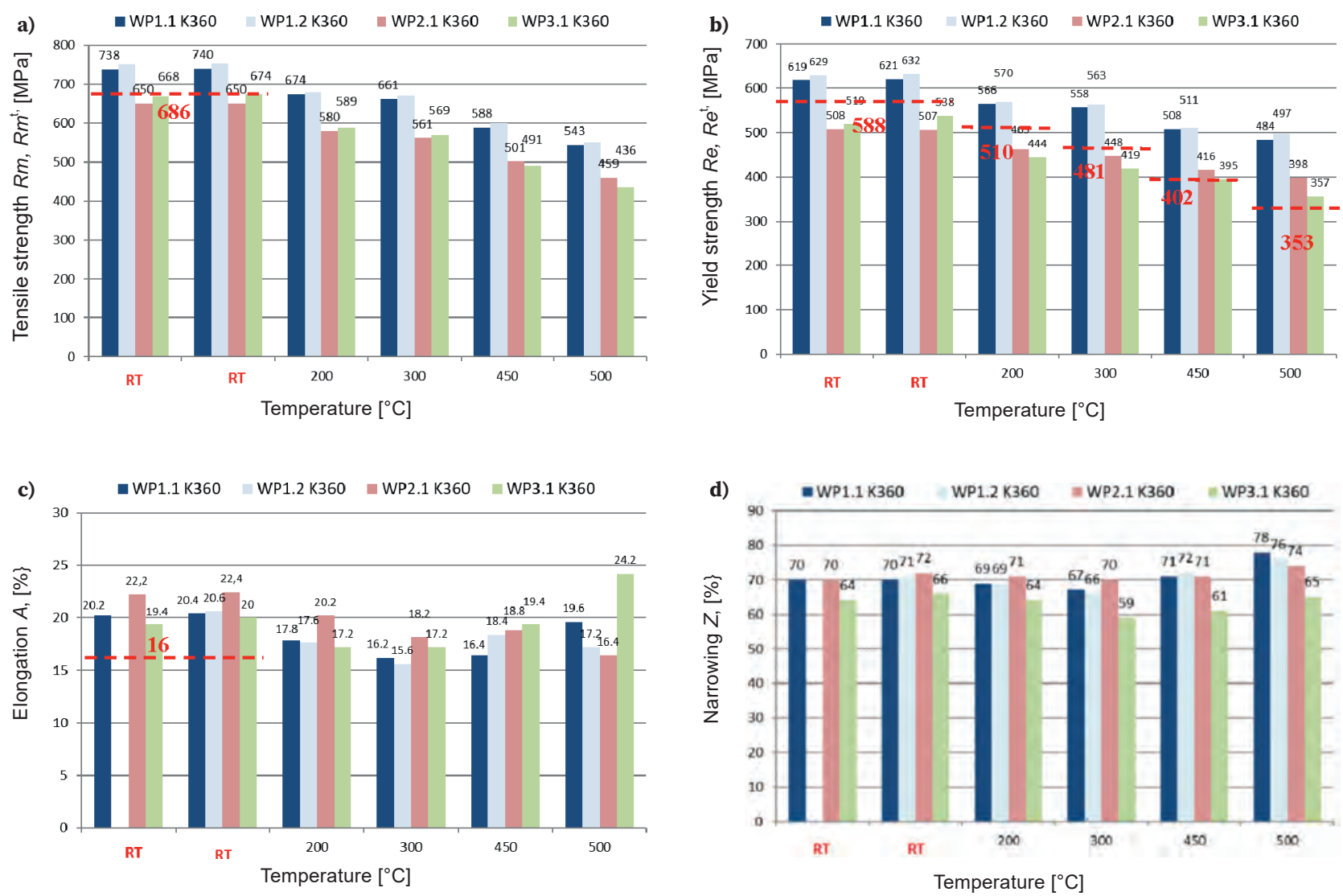

red marks the requirements for the material in the initial state

Fig. 8. Strength properties at room and elevated temperature for the material of the WP high-pressure of the $18 \mathrm{~K} 360$ turbine rotor after 220,000 hours of operation: tensile strength, b) yield strength, c) elongation in tensile test, d) compression in tensile test

Rys. 8. Właściwości wytrzymałościowe w temperaturze pokojowej i podwyższonej materiału części wysokoprężnej WP wirnika turbiny $18 K 360$ po 220000 godzin eksploatacji: a) wytrzymałość na rozciaganie, b) granica plastyczności, c) wydłużenie w próbie rozciąania, d) przewężenie w próbie rozciągania

Table 5. Impact energy measured on V-notch samples depending on the test temperature and the temperature of transition to brittle condition of the material of the WP high-pressure part of the TK200 turbine rotor after 200,000 hours of operation, and the SP medium-pressure part and WP high-pressure part of the $18 \mathrm{~K} 360$ turbine rotor after 220,000 hours of operation

Tabela 5. Praca łamania mierzona na próbkach $\mathrm{z}$ karbem $\mathrm{V}$ w zależności od temperatury badania i temperatura przejścia $\mathrm{w}$ stan kruchy materiału części wysokoprężnej WP wirnika turbiny TK200 po 200000 godzin eksploatacji oraz części średnioprężnej SP i wysokoprężnej WP wirnika turbiny $18 \mathrm{~K} 360$ po 220000 godzin eksploatacji

\begin{tabular}{|c|c|c|c|c|c|c|c|c|c|c|c|}
\hline \multirow{2}{*}{$\frac{\text { Component name }}{\text { operating time }}$} & \multirow{2}{*}{$\frac{\text { Testing location }}{\text { identification }}$} & \multicolumn{9}{|c|}{$\begin{array}{l}\text { Impact energy } \mathrm{KV},[\mathrm{J}]^{1)} \\
\text { at temperature, }\left[{ }^{\circ} \mathrm{C}\right]\end{array}$} & \multirow{2}{*}{$\begin{array}{c}\text { Brittle state } \\
\text { transition } \\
\text { temperature, } \\
{\left[{ }^{\circ} \mathrm{C}\right]}\end{array}$} \\
\hline & & -20 & -10 & $\mathbf{0}$ & 10 & $R T^{2)}$ & 40 & 60 & 90 & 98 & \\
\hline $\begin{array}{l}\text { TK200 } \\
\text { WP high-pressure part } \\
200,000 \text { operating hours }\end{array}$ & $\begin{array}{l}\text { from outer periphery } \\
\text { uncontrolled rotor's first stage } \\
\text { (ID WP.TK200) }\end{array}$ & - & - & 7 & - & 11 & - & 21 & 37.5 & - & approx. +70 \\
\hline \multirow{2}{*}{$\begin{array}{l}18 \mathrm{~K} 360 \\
\text { SP medium-pressure part } \\
220,000 \text { operating hours }\end{array}$} & $\frac{\text { carrier thrust bearing pin }}{\text { (ID SP } 1.1 \mathrm{~K} 360)}$ & 18.3 & 30 & 53.5 & - & 132 & - & - & - & - & approx. -15 \\
\hline & $\frac{\text { rotor's drum in steam inlet area }}{\text { (ID SP } 2.1 \mathrm{~K} 360)}$ & 23 & - & 24 & 32 & 42 & 52 & - & - & - & approx. + 5 \\
\hline \multirow{3}{*}{$\begin{array}{l}18 K 360 \\
\text { WP high-pressure part } \\
220,000 \text { operating hours }\end{array}$} & $\underline{\text { rotor tip on safety control side }}$ & - & - & 8.6 & & 24.3 & - & - & - & - & RT \\
\hline & $\frac{\text { drum in stage } 12-13 \text { region }}{\text { (ID WP } 2.1 \mathrm{~K} 360)}$ & - & - & 10.3 & - & 20.3 & 35 & 77 & - & 156 & approx. +35 \\
\hline & $\frac{\text { steam inlet in control wheel region }}{\text { (ID WP } 3.1 \mathrm{~K} 360)}$ & - & - & 8.6 & - & 19.3 & 33.3 & 79.3 & - & - & approx. +40 \\
\hline
\end{tabular}

\footnotetext{
1) average values

${ }^{2)} \mathrm{RT}$ - room temperature
} 
a)
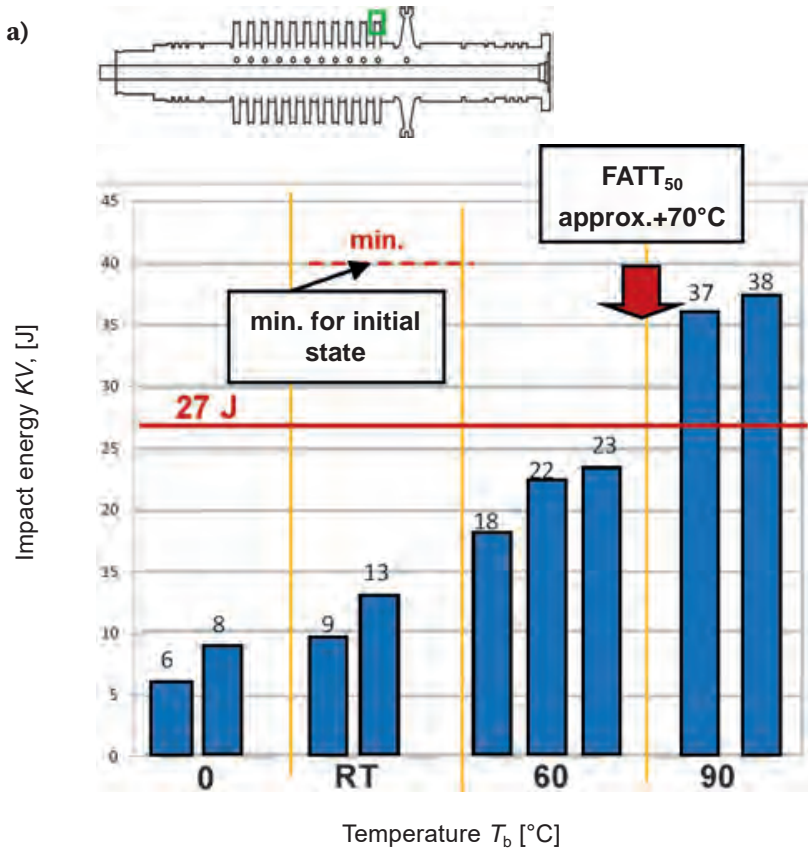

b)
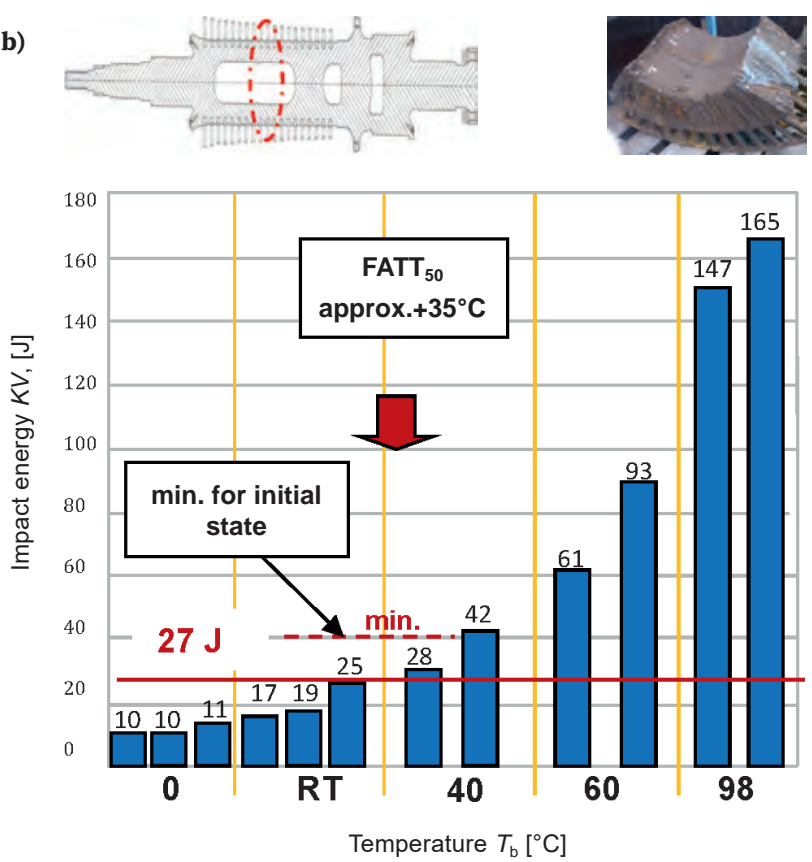

Fig. 9. Impact energy and temperature of transition into brittle state on the example of materials of selected sections of the WP high-pressure part of $21 \mathrm{HMF}$ steel turbine rotors of the $200 \mathrm{MW}$ unit after 200,000 operating hours (ID WP.TK200), b) of the 360 MW unit after 220,000 operating hours (ID WP2.1 K360)

Rys. 9. Praca łamania i temperatura przejścia w stan kruchy na przykładzie materiałów wybranych wycinków części wysokoprężnej WP wirników turbin parowych wykonanych ze stali 21HMF a) bloku 200 MW po 200 tys. godzin eksploatacji (ozn. WP.TK200), b) bloku 360 MW po 220 tys. godzin eksploatacji (ozn. WP2.1 K360)

a)

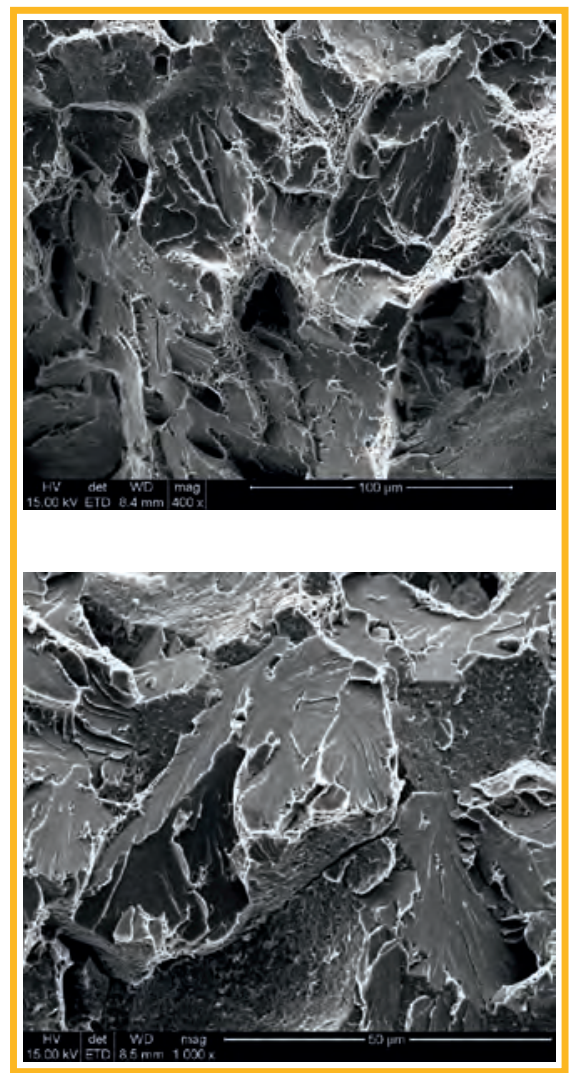

b)

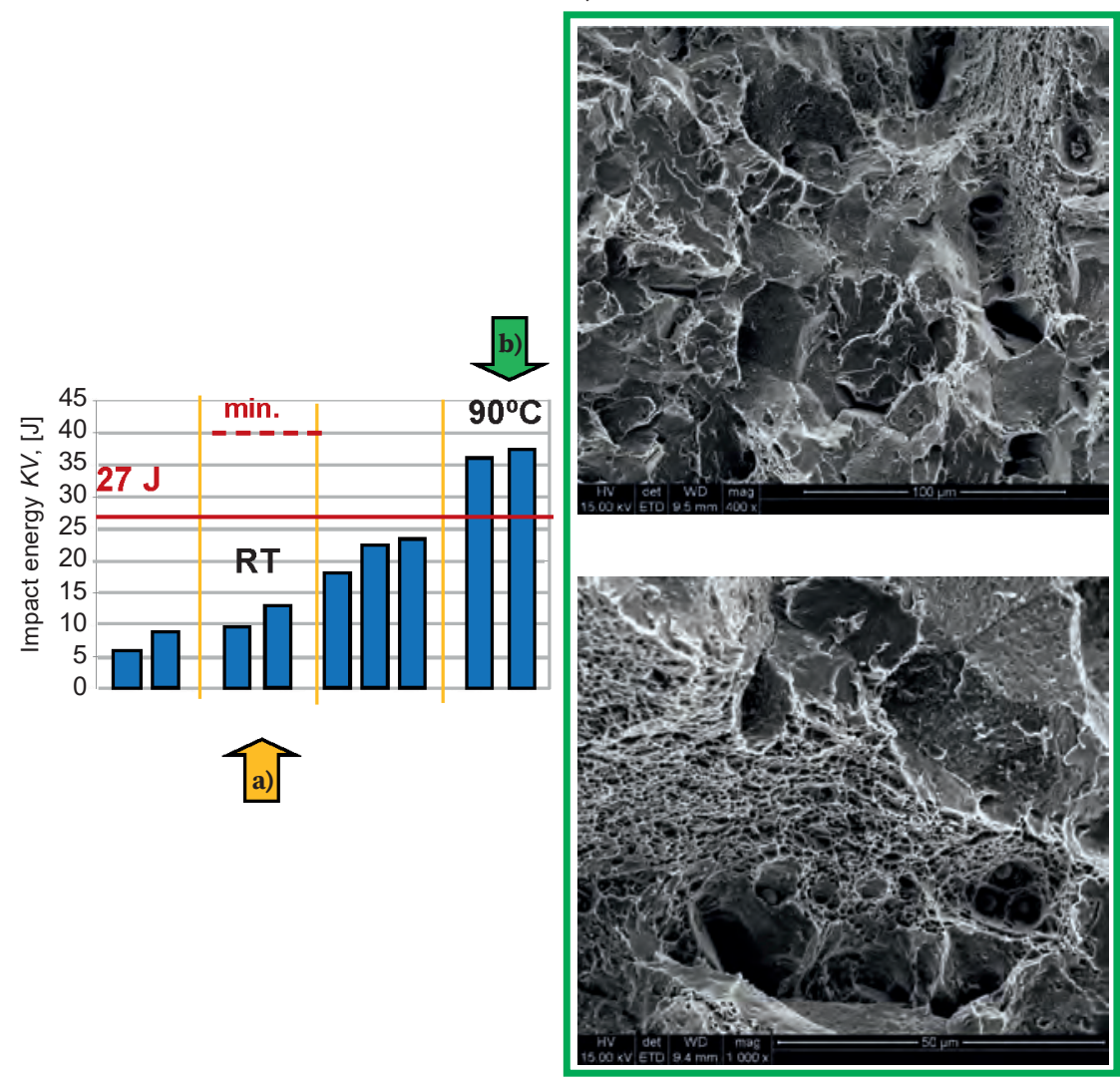

Fig. 10. Fractographic images of fractures of impact samples of the tested material of the WP high-pressure part of 21HMF steel steam turbine rotor of a $200 \mathrm{MW}$ block after 200,000 operating hours: a) impacted at room temperature, b) impacted at $+90^{\circ} \mathrm{C}$

Rys. 10. Obrazy fraktografii przełomów próbek udarnościowych materiału badanego wycinka części wysokoprężnej WP wirnika turbiny parowej bloku 200 MW po 200 tys. godzin eksploatacji wykonanego ze stali 21HMF: a) złamanej w temperaturze pokojowej, b) złamanej w temperaturze $+90^{\circ} \mathrm{C}$ 
The determined temperature of transition into brittle state for the tested materials after long-term operation is significantly above room temperature, i.e. from +5 to $+70^{\circ} \mathrm{C}$, which is a disadvantageous feature of the tested materials. This may require an analysis of the applicable unit start-up and shut-down procedures and their verification to ensure continued safe operation.

Only the results of impact strength tests of the material of the carrier thrust bearing pin (ID SP $1.1 \mathrm{~K} 360$ ) and the drum material in the area of the steam inlet (ID SP 2.1 K360) of the SP part of the turbine rotor meet the requirements for the initial state at room temperature and the expected minimum impact energy of $27 \mathrm{~J}$. The determined temperature of transition into brittle state for the tested materials after long-term operation is at a negative temperature $\left(-15^{\circ} \mathrm{C}\right)$ for the state corresponding to the initial state, and for operation at $535^{\circ} \mathrm{C}$ - at a positive temperature $\left(+5^{\circ} \mathrm{C}\right)$.

The fractograph of the fractures on broken impact samples for selected test temperature levels revealed in the scanning electron microscope for a selected representative example, i.e. the material of the WP high-pressure part of the $200 \mathrm{MW}$ unit turbine rotor after 200,000 operating hours is shown in Fig. 10. In particular, Fig. 10a shows examples of the fracture morphology of an impact sample at room temperature with the obtained impact energy value of $9 \mathrm{~J}$, while Fig. 10b shows images of the fracture formed at $+90^{\circ} \mathrm{C}$ with an impact energy value of $38 \mathrm{~J}$. At room temperature, a brittle fracture was obtained with small areas of ductile fracture, while at a temperature of $+90^{\circ} \mathrm{C}$, a mixed fracture occurred with a predominance of brittle fracture.

\section{ANALYSIS OF RESULTS}

The aim of the research was to assess the material condition of the medium-pressure and high-pressure parts of steam turbine rotors after long-term operation significantly exceeding the calculated design time and to determine the suitability of these materials for further operation with defined temperature and stress parameters. The joint analysis of the state of the structure and basic mechanical properties was the basis for the selection of material for creep tests aimed at determining residual life, residual disposable life and the degree of wear. The tested materials were selected so that they were characterised by the degree of depletion in the range from the state close to the characteristic for the initial state to the most worn-out one. An estimated degree of depletion was adopted as a measure of wear.

The material for the studies was collected from the turbine rotor elements components which operated at a temperature slightly above room temperature or at a temperature well below the limit. This relates to the material of the carrier thrust bearing pin (ID SP1.1 K360) and front of the gland (ID SP1.2 K360) of the SP medium-pressure part, material of the rotor tip on the safety control side (ID WP1.1 $\mathrm{K} 360$ ), place of embedding of device components for rotor turning (ID WP1.2 K360) and bearing pin (ID WP1.3 K360) of the WP part. All these materials are characterised by the state of the structure similar to the original state. This is evidenced by both the disclosed image of the structure observed in the scanning electron microscope and the sequence of carbides revealed in X-ray tests of deposit isolates. The characteristic structure is the lamellar form of bainite with a small amount of ferrite and a large amount of precipitates with a different proportion and morphology identified on the basis of morphological features and X-ray analysis.

The dominant precipitates in the observed microstructure are the $\mathrm{M}_{3} \mathrm{C}$ and $\mathrm{M}_{7} \mathrm{C}_{3}$ carbides, which coagulate with the extended service life, showing a tendency to form chain systems. The stability of the strength properties and the durability of components made of $21 \mathrm{HMF}$ steel are significantly influenced by MC dispersed precipitates. The material atrophy processes are evidenced by the presence of disc molybdenum-rich $\mathrm{Mo}_{2} \mathrm{C}$ precipitates.

The tested materials were assigned the structural class 0 and the corresponding degree of wear of 0 . The correct assessment is confirmed by the obtained values of basic mechanical properties, which are much higher than the minimum required for the initial state, the transition temperature to the brittle state, which is equal to or lower than room temperature, and the hardness level corresponds to the values characteristic for the initial state.

The remaining materials were collected from turbine rotor components, the operating temperature of which was above the limit temperature, where creep is the dominant destruction process, although their operating temperature varied significantly, and the operating time was 200,000 or 220,000 hours, respectively, and was at least twice the design time. This resulted in the differentiation of the degree of depletion, the measure of which is the estimated degree of wear.

The material with a low degree of wear $\left(t_{\mathrm{e}} / t_{\mathrm{r}}=\right.$ approx. 0.2 ) was collected from a rotor drum in the steam inlet region (ID SP $2.1 \mathrm{~K} 360$ ) of the SP medium-pressure part of the $360 \mathrm{MW}$ unit turbine rotor with an operating temperature of $535^{\circ} \mathrm{C}$. It is characterised by a bainite structure with a small amount of ferrite with a slight degree of bainite degradation and a moderate development of precipitation processes. Apart from a significant amount of precipitates of $\mathrm{M}_{3} \mathrm{C}$ carbides and numerous fine $\mathrm{MC}$ and $\mathrm{M}_{2} \mathrm{C}$ carbides inside the bainitic regions, as for the material in the initial state, $\mathrm{M}_{7} \mathrm{C}_{3}$ precipitates were identified at the boundaries of bainite regions and ferrite grains, although with different proportions compared to the initial state. This state corresponds to class o/a of the precipitation process development and structural class 1 . The set of mechanical properties also corresponds to values higher than the minimum required for the initial state; the brittle transition temperature is approx. $+5^{\circ} \mathrm{C}$ and the hardness is $247 \mathrm{HV} 10$.

Material with a significant degree of wear $\left(t_{\mathrm{e}} / t_{\mathrm{r}}=\right.$ approx. 0.3-0.4) is a material collected from a drum fragment in the region of stage 12-13 (ID WP $2.1 \mathrm{~K} 360$ ) of the WP high-pressure part of the turbine rotor of the $360 \mathrm{MW}$ unit after long-term operation with an operating temperature of $510^{\circ} \mathrm{C}$. It is characterised by a bainite structure with partial lamellae disappearance and numerous precipitates at lamellae boundaries and inside them. Chain-forming precipitates, probably of the chromium-rich $\mathrm{M}_{7} \mathrm{C}_{3}$ carbide, were observed at the boundaries of bainite lamellae. Also inside these areas, a significant number of precipitates were revealed, which can be identified by their morphological features as finely-dispersed VC and $\mathrm{Mo}_{2} \mathrm{C}$ precipitates. This was confirmed by the results of studies on the isolates of precipitates, the defined sequence of which corresponds to class a of the degree of development of the precipitation processes, and together with the revealed structure image, corresponds to class 2 . The consequence of the partial degradation of the structure is the reduction of the basic strength properties, in particular the tensile strength and yield point at room temperature as well as the 
yield point at 200 and $300^{\circ} \mathrm{C}$, the obtained values of which are significantly lower than the minimum required for the initial state. Also, the impact energy at room temperature is much lower than that required for the initial state, and the brittle transition temperature is positive and amounts to $+35^{\circ} \mathrm{C}$. Moreover, there was a reduction in hardness, which is much lower than expected for the initial state and amounts to $210 \mathrm{HV} 10$.

The material with a significant degree of wear $\left(t_{\mathrm{e}} / t_{\mathrm{r}}=\right.$ approx. 0.4) is taken from the outer periphery of the disc of the first unregulated stage (ID WP.TK200) of the high-pressure part of the turbine rotor of the $200 \mathrm{MW}$ unit after longterm operation with an operating temperature of $500^{\circ} \mathrm{C}$ and taken from the area of the control wheel (ID WP 3.1K360, WP 3.4K360) of the high-pressure part of the turbine rotor of the $3600 \mathrm{MW}$ unit after long-term operation with the operating temperature of $535^{\circ} \mathrm{C}$, differing not only in temperature, but also in operating time, by approx. 20,000 hours. These materials are characterised by bainitic structure with a significant disappearance of bainite lamellae are characterised by an advanced precipitation process, which is evidenced by numerous fine precipitates inside these areas. Based on their morphological features, it can be assumed that these are fine spheroidal precipitates of the vanadium-rich $\mathrm{MC}$ carbide and elongated precipitates of the molybdenum-rich $\mathrm{M}_{2} \mathrm{C}$ carbide. The chain-forming precipitates that occur at the boundaries of these regions are likely precipitates of chromium-rich $\mathrm{M}_{7} \mathrm{C}_{3}$ or $\mathrm{M}_{23} \mathrm{C}_{6}$ carbide. This was confirmed by the results of studies on the isolates of precipitates, the defined sequence of which corresponds to class a of the degree of development of the precipitation processes, and together with the revealed structure image, corresponds to class 2/3. A significant degradation of the structure manifested itself in the level of strength properties lower than the required minimum values for the initial state, in particular tensile strength and yield point at room temperature and yield point at 200,300 and $450^{\circ} \mathrm{C}$ for the material from the $360 \mathrm{MW}$ block, ID WP 3.1K360. For the rotor material from the $200 \mathrm{MW}$ unit ID WP.TK200, the actual obtained values of tensile strength and yield strength, both at room temperature and elevated temperature, are much higher than the minimum required for the initial state. This may be due to their baseline level significantly higher than the required minimum values, which resulted in a significant reduction, but to a level above the required minimum baseline values. On the other hand, the results of the impact energy test showed that its level at room temperature for both analysed materials is much below the required minimum value for the initial state and amounts to
$11 \mathrm{~J}$ for the WP part turbine rotor material of the $200 \mathrm{MW}$ power unit ID WP.TK200, and for the WP part turbine rotor material of the $360 \mathrm{MW}$ unit ID WP 3.1K360 it is $19 \mathrm{~J}$. The determined brittle transition temperature is 70 and $40^{\circ} \mathrm{C}$, respectively, and the hardness is 195 and $210 \mathrm{HV} 10$, respectively.

Moreover, none of the tested materials showed internal damage due to creep, which indicates the advancement of the creep process at the stage of the second creep period, i.e. in the steady state and significantly before its completion, which is confirmed by the estimated degree of wear.

\section{CONCLUSIONS}

The following conclusions may be drawn based on the study:

1. The tested materials, which are steam turbine rotor components, after operation in a time exceeding the design time twice, are characterised by the degree of wear from $t_{\mathrm{e}} / t_{\mathrm{r}}=$ approx. 0 and the corresponding structural class 0 to those characterised by the degree of wear $t_{\mathrm{e}} / t_{\mathrm{r}}=$ approx. 0.4 and the corresponding structural class $2 / 3$.

2. Changes in the structure of materials after long-term operation, defined by the estimated degree of wear $\left(t_{\mathrm{e}} / t_{\mathrm{r}}=\right.$ approx. 0.3-0.4 and 0.4), resulted in a reduction of the basic strength properties both at room temperature and elevated temperature. These changes also resulted in the reduction of impact energy to values below the minimum required for the initial state, with a simultaneous significant increase in the temperature of transition to brittle state, which is a positive value.

3. The assessment of the condition of the turbine rotors' material after long-term operation (structures and properties) was the basis for the selection of turbine rotor materials with various levels of degree of wear for further research including the definition of their creep resistance. The combined results of these studies will enable the creation of material characteristics of the low-alloy 21HMF three-component steel from the initial state to the state after long-term operation above the limit temperature with a significant degree of wear, which will be the basis for a reliable assessment of the condition and prognosis of further safe operation based on material diagnostics.

The article contains partial results of studies obtained in the statutory work of Eukasiewicz - IMŻ and financed by the Ministry of Science and Higher Education for 2020.

\section{REFERENCES}

[1] J. Dobrzański. Materials science interpretation of the life of steels for power plants, Gliwice: Open Access Library, 3, 2011.

[2] J. Dobrzański. Trwatość elementów ciśnieniowych bloków energetycznych. Gliwice: Wydawnictwo Instytutu Metalurgii Żelaza 2019. Monograph No. 12.

[3] A. Hernas, J. Dobrzański. Trwałość i niszczenie elementów kottów turbin parowych. Gliwice: Wydawnictwo Politechniki Śląskiej, 2003.

[4] J. Dobrzański, H. Purzyńska. Badania materiałowe w ocenie stanu i prognozowaniu dalszej bezpiecznej eksploatacji wirników turbin parowych po przekroczeniu obliczeniowego czasu Pracy. Energetyka, 2015, 11, pp. 761-764.

[5] A. Zieliński, H. Purzyńska, J. Dobrzański, G. Golański. Changes in properties and structure of high-chromium $9-12 \% \mathrm{Cr}$ steels due to long-term exposure at elevated temperature. Archives of Metallurgy and Materials, 2016, 61 (2B), pp. 957-964.
[6] J. Dobrzański, A. Rusin, H. Purzyńska, A. Zieliński. Wysokochromowe stale nowej generacji na wirniki turbin parowych bloków energetycznych o nadkrytycznych parametrach pracy. In: Maszyny i urzadzenia energetyczne wẹglowych bloków na wysokie parametry pary. Gliwice: Wydawnictwo Politechniki Ślaskiej, 2015, pp. 95-124.

[7] M. Dziuba-Kałuża, J. Dobrzański, H. Purzyńska, Z. Kania-Pifczyk, R. Rozmus. Ocena stopnia wyeksploatowania materiału wirników turbin parowych z niskostopowej stali Cr-Mo-V po eksploatacji w czasie znacznie przekraczającym czas obliczeniowy. Prace Instytutu Metalurgii Żelaza, 2018, 70 (1), pp. 4-11. 